\title{
Adsorption characteristics of ethanol onto functional activated carbons with controlled oxygen
}

\section{content}

\author{
Kutub Uddin ${ }^{1,5}$, Ibrahim I. El-Sharkawy ${ }^{2,3,5}$, Takahiko Miyazaki ${ }^{2,5}$, Bidyut Baran Saha ${ }^{1,5, *}$, Shigeru \\ Koyama $^{1,2,5}$, \\ Hyun-Sig Kil ${ }^{4}$, Jin Miyawaki ${ }^{4}$, Seong-Ho Yoon ${ }^{4}$ \\ ${ }^{1}$ Interdisciplinary Graduate School of Engineering Sciences, Kyushu University \\ Kasuga Koen 6-1, Kasuga-shi, Fukuoka 816-8580, Japan \\ ${ }^{2}$ Faculty of Engineering Sciences, Kyushu University \\ Kasuga Koen 6-1, Kasuga-shi, Fukuoka 816-8580, Japan \\ ${ }^{3}$ Mechanical Power Engineering Department, Faculty of Engineering \\ Mansoura University, El-Mansoura 35516, Egypt \\ ${ }^{4}$ Institute for Materials Chemistry and Engineering, Kyushu University \\ Kasuga Koen 6-1, Kasuga-shi, Fukuoka 816-8580, Japan \\ ${ }^{5}$ International Institute for Carbon-Neutral Energy Research (WPI-I2CNER), Kyushu University \\ 744 Motooka, Nishi-ku, Fukuoka 819-0395, Japan \\ *Author to whom correspondence should be addressed, \\ E-mail: saha.baran.bidyut.213@m.kyushu-u.ac.jp
}

\begin{abstract}
The present study aims to investigate adsorption characteristics of ethanol onto activated carbon powders namely; parent Maxsorb III and surface treated Maxsorb III with controlled oxygen content. Experiments have been conducted gravimetrically using a magnetic suspension adsorption measurement unit. The measurements have been conducted within evaporator temperatures range from -14 to $77{ }^{\circ} \mathrm{C}$ and adsorption temperatures between 20 and $80{ }^{\circ} \mathrm{C}$. The Dubinin-Astakhov (D-A) adsorption model is found to be suitable to correlate the adsorption isotherm data. The isosteric heat of
\end{abstract}


adsorption of the assorted adsorbent/refrigerant pairs has been estimated using Clausius-Clapeyron and the D-A equations. Effect of the refrigerant purity on the adsorption characteristics of the adsorbent/refrigerant pair is also discussed. The data extracted from this study are useful for the design of adsorption cooling, refrigeration and heat pump systems.

Keywords: activated carbon; adsorption characteristic; ethanol; isosteric heat of adsorption

\section{Nomenclature}

$\begin{array}{ll}A & \text { adsorption potential, } \mathrm{kJ} / \mathrm{kmol} \\ E & \text { adsorption characteristic parameter, } \mathrm{J} / \mathrm{mol} \\ n & \text { exponent fitting parameter used in the D-A equation } \\ P & \text { equilibrium pressure of refrigerant, } \mathrm{kPa} \\ P_{S} & \text { saturation pressure of refrigerant at adsorption temperature, } \mathrm{kPa} \\ Q_{s t} & \text { isosteric heat of adsorption, } \mathrm{kJ} / \mathrm{kg} \\ R & \text { universal gas constant, } \mathrm{J} / \mathrm{mol} \mathrm{K} \\ T & \text { temperature, } \mathrm{K} \\ W & \text { equilibrium uptake, } \mathrm{kg} / \mathrm{kg} \\ W_{0} & \text { maximum adsorption capacity, } \mathrm{kg} / \mathrm{kg}\end{array}$

\section{Introduction}

The thermally powered adsorption cooling and heat pump systems got considerable attention in the past few decades due to the awareness of global warming and ozone depletion problems. The main advantages of adsorption systems over the conventional cooling systems are: (i) the ability to use 
refrigerants having zero ozone depletion potential (ODP) and low global warming potential (GWP), (ii) these systems can be driven by low grade thermal energy, (iii) almost no electricity usage, and (iv) the simplicity of operation. Extensive studies have been conducted to investigate the performance of adsorption cooling/heat pump systems considering various adsorbent/refrigerant pairs, such as silica gel/water, zeolite/water, carbon/ammonia, activated carbon/methanol, activated carbon/ethanol and other working pairs [1-11]. The high adsorption capacity of ethanol and methanol onto highly porous activated carbons and low regeneration temperature (below $100^{\circ} \mathrm{C}$ ) makes it possible to use these working pairs in solar adsorption cooling application $[10,11]$.

Adsorption characteristics of adsorbent/refrigerant pairs in terms of adsorption isotherms, kinetics and isosteric heat of adsorption are essential for the optimum design and development of adsorption cooling and heat pump systems. Adsorption isotherms describe the equilibrium uptake at a given equilibrium pressure and adsorption temperature. The most common techniques used for measuring adsorption isotherms are; (i) gravimetric method using thermogravimetric analyzer (TGA) unit [12-16] or magnetic suspension balance (MSB) [17-18], (ii) chromatographic method [19], (iii) constant volume variable pressure (CVVP) method [20-21], (iv) measuring the liquid refrigerant level at evaporator side $[8,10]$, and (v) desorption method [22]. It is proven that the gravimetric method employing TGA or the magnetic suspension balance provides high accuracy of adsorption equilibrium and kinetic measurements. El-Sharkawy et al. [11] measured the adsorption equilibrium of ethanol onto activated carbon powder, namely parent Maxsorb III, for solar powered adsorption cooling applications using a TGA unit of type Chan-2121coupled with a controlled temperature evaporator. Hornbostel et al. [16] studied the characteristics of carbon sorbent for $\mathrm{CO}_{2}$ capture using a temperature programmed TGA. Saha et al. [17] studied the adsorption characteristics of R134a onto activated carbons using Rubotherm 
ISOSORP 2000 within evaporation temperatures between -20 and $40{ }^{\circ} \mathrm{C}$ and adsorption temperatures ranges from 30 to $80{ }^{\circ} \mathrm{C}$ for refrigeration and cooling applications.

In the present study an automated controlled magnetic suspension adsorption measurement unit of type MSB-VG-S2 has been used to investigate the adsorption characteristics of environment friendly refrigerant ethanol onto activated carbons, namely parent Maxsorb III, $\mathrm{KOH}-\mathrm{H}_{2}$ treated Maxsorb III and $\mathrm{H}_{2}$ treated Maxsorb III within evaporation temperature ranges between -14 to $77{ }^{\circ} \mathrm{C}$ and adsorption temperature from 20 to $80{ }^{\circ} \mathrm{C}$. This paper emphasizes the evaluation of adsorption equilibrium and isosteric heat of adsorption of the assorted pair. Effect of the refrigerant purity on the isotherms parameters of adsorbent/refrigerant pairs derived from popular models have also been discussed.

\section{Experiments}

\subsection{Materials}

Adsorbents used in the present study are parent Maxsorb III, KOH- $\mathrm{H}_{2}$ treated Maxsorb III and $\mathrm{H}_{2}$ treated Maxsorb III. The sample, $\mathrm{H}_{2}$ treated Maxsorb III is prepared by placing parent Maxsorb III in a reduction environmental condition $\left(\mathrm{Ar} / \mathrm{H}_{2}=8 / 2(\mathrm{v} / \mathrm{v})\right)$ at a temperature of $600{ }^{\circ} \mathrm{C}$ for $24 \mathrm{~h}$. To prepare the $\mathrm{KOH}-\mathrm{H}_{2}$ treated Maxsorb III, potassium hydroxide $(\mathrm{KOH})$ treatment was applied to $\mathrm{H}_{2}$ treated Maxsorb III at different weight ratios and the mixture is heat treated at temperature between 600 and $750{ }^{\circ} \mathrm{C}$ for $1 \mathrm{~h}$ under nitrogen flow and finally washed with $\mathrm{HCl}$ to adjust the $\mathrm{pH}$ value of about 7 [23].

Figure 1 shows the SEM pictures of the studied adsorbents whilst their elemental compositions are summarized in Table1. The particle size distributions of the assorted adsorbents have been measured by El-Sharkawy et al. [24]. It can be seen from Table 1 that the parent Maxsorb III contains $0.13 \%$ of ash and $4.35 \%$ of oxygen whilst the $\mathrm{H}_{2}$ treated Maxsorb III and $\mathrm{KOH}-\mathrm{H}_{2}$ treated Maxsorb III having no ash 
and the oxygen contents varies between 1.75 and $10.46 \%$, respectively. It is worthy to mention that, for polar molecules such as ethanol, surface functional groups should have a strong influence on the adsorption behaviors. Therefore, the main intention for the treatment is to clarify such influence by changing oxygen contents of activated carbon maintaining very similar thermophysical properties (specific surface area, pore volume, and pore size). The refrigerant used in the present study is ethanol with a purity of $95 \%$. A sample of ethanol is tested and its compositions are furnished in Table 2. As ethanol has few percentages of other components, it is considered to behave like a pseudo pure component at the evaporator temperature.

\subsection{Instrumentation}

The experimental apparatus consists mainly of the magnetic suspension adsorption measurement unit, ultrahigh vacuum system, a controlled temperature evaporator, isothermal circulation oil bath that controls adsorption and evaporation temperature, and isothermal air bath to avoid condensation through connecting tubes. The suspension balance system makes it possible to weigh samples contactless instead of direct contact between the measuring cell and the weighing instrument. The suspension magnet consists of a permanent magnet, a sensor core and electronic control unit [25]. Figure 2 shows the schematic diagram of the magnetic suspension balance section. It should be highlighted that buoyancy effect on the measurements is considered automatically by the system. The diaphragm pump, rotary pump and turbo molecular pump work sequentially to reach the ultrahigh vacuum condition (less than $\left.3 \times 10^{-5} \mathrm{~Pa}\right)$.

All the valves of the system are functioned automatically using $\mathrm{N}_{2}$ gas following the provided setting condition. The measurement data are recorded continuously. The temperatures and pressure in the 
evaporator, sorption cell and connecting tubes are measured with platinum thermocouples and high accuracy absolute pressure gauges, respectively.

\subsection{Experimental procedure}

The magnetic suspension adsorption measurement unit was used to measure the adsorption characteristics of ethanol adsorption onto functional activated carbon within evaporation temperature ranges from -14 to $77^{\circ} \mathrm{C}$ and adsorption temperature between 20 and $80{ }^{\circ} \mathrm{C}$. Experiments have been conducted using the multi-step technique where adsorption temperature is kept constant and evaporator temperature increased step by step until reaching a relative pressure of about 0.9. Experimental procedure for each isotherm measurement can be explained as follows;

(i) firstly, the sorbent sample is heated at $120{ }^{\circ} \mathrm{C}$ for about 4 hours in a vacuum condition of about $3 \times 10^{-5} \mathrm{~Pa}$ to remove any adsorbed gas on the sample. After that, the sorbent is cooled down to the set adsorption temperature where the system considered the buoyancy effect of the measurements,

(ii) valve between evaporator and adsorption chamber is then opened to allow ethanol vapor to flow towards adsorbent sample. After that, adsorption process starts where adsorption uptake is continuously measured using the magnetic suspension balance until reaching the equilibrium conditions corresponding to the set relative pressure,

(iii) valve between evaporator and adsorption chamber is closed and evaporator temperature increased to prepare for the next relative pressure step,

(iv) process (ii) and (iii) are repeated for each relative pressure.

To avoid condensation, the piping system was always kept at $20{ }^{\circ} \mathrm{C}$ higher than the saturation temperature of the vapor, which was achieved by isotherm air bath around the piping system. 


\section{Data Reduction}

\subsection{Adsorption equilibrium}

The Dubinin-Astakhov (D-A) [26, 27] equation is widely accepted for adsorption equilibrium of gases and vapors onto microporous adsorbents. The D-A adsorption isotherm model (Eq. 1) is used to fit the measured adsorption equilibrium uptake for ethanol onto parent Maxsorb III, $\mathrm{KOH}-\mathrm{H}_{2}$ treated Maxsorb III and $\mathrm{H}_{2}$ treated Maxsorb III.

$$
W=W_{0} \exp \left[-\left\{\frac{A}{E}\right\}^{n}\right]
$$

Where $A$ is the adsorption potential that can be estimated using Eq. (2);

$$
A=R T \ln \left(\frac{P_{S}}{P}\right)
$$

Linearization of Eq. (2) yields equation (3) below;

$$
\ln W=\ln W_{0}-\frac{1}{E^{n}}\left\{R T \ln \left(\frac{P_{S}}{P}\right)\right\}^{n}
$$

Where $W$ stands for the equilibrium uptake $(\mathrm{kg} / \mathrm{kg})$ of the adsorbent/refrigerant pair, $W_{0}$ defines the maximum adsorption capacity $(\mathrm{kg} / \mathrm{kg})$ and $E$ is the adsorption characteristic parameter of the adsorbent/adsorbate pair $(\mathrm{J} / \mathrm{mol})$ and can be evaluated experimentally. The exponential parameter $n$ gives the best fitting of $\ln (W)$ versus $A^{n}$. In Eq. (2), $T$ is the adsorption temperature $(K), P_{s}$ defines the saturation pressure of refrigerant at adsorption temperature $(\mathrm{kPa})$ whilst $P$ is the equilibrium pressure $(k P a)$. 


\subsection{Isosteric heat of adsorption}

The isosteric heat of adsorption $\left(Q_{s t}\right)$, that is defined as the difference between the activation energy for adsorption and desorption, represent the strength of adsorbate-adsorbent interaction [28]. Quantification of $Q_{s t}$ is very important for kinetic studies of adsorption process because the heat released upon adsorption is partially adsorbed by the adsorbent which causes a rise in adsorbent temperature and thus influences the rate of adsorption [29]. The isosteric heat of adsorption is hard to be measured experimentally. The numerical value of isosteric heat of adsorption at constant uptake is estimated from adsorption equilibrium data using Clausious -Clapeyron equation which is given by;

$$
\frac{-Q_{s t(C C)} M}{R}=\frac{\partial \ln P}{\partial\left(\frac{1}{T}\right)}
$$

$Q_{s t}$ is the isosteric heat of adsorption $(\mathrm{kJ} / \mathrm{kg})$ which is a negative quantity because of exothermic adsorption process. $R$ is the universal gas constant $(\mathrm{kJ} / \mathrm{kmol} . \mathrm{K}), \mathrm{M}$ is molar constant $(\mathrm{kg} / \mathrm{kmol})$. The partial differentiation is performed at constant concentration.

Heats of adsorption published in the literature are often showing a big difference which means a dearth of theoretical formulation that could accurately represent the value in a wide range of uptake. There are some correlations to calculate the isosteric heat of adsorption. Chakraborty et al. [30] described a thermodynamic framework to derive an expression for isosteric heat of adsorption which is then verified with experimental data. El-Sharkawy et al. [31] proposed a non-dimensional empirical correlation for isosteric heat of adsorption on carbon based adsorbents. Shen et al. [32] presented a comparative study among some experimental techniques for measuring the isosteric heat of adsorption. 
The wide range of isosteric heat for adsorbate/adsorbent pairs are dependent on the selected isotherm equation used in modeling the adsorbed phase. In this study a simplified method for isosteric heat of adoption is proposed using the D-A isotherm model along with Van't Hoff equation [33]. Starting with the D-A equation, isosteric heat of adsorption equation can be derived as follows;

$\ln \left(\frac{W}{W_{0}}\right)=-\left\{\frac{R T}{E} \ln \left(\frac{P}{P}\right)\right\}^{n}$

Rearranging Eq. (5), one can write;

$\ln \left(\frac{P_{s}}{P}\right)=\frac{E}{R T}\left\{-\ln \left(\frac{W}{W_{0}}\right)\right\}^{1 / n}$

Therefore;

$P=\frac{P_{s}}{\exp \left[\frac{E}{R T}\left\{-\ln \left(\frac{W}{W_{0}}\right)\right\}^{1 / n}\right]}$

or $\ln P=\ln \left(P_{s}\right)-\frac{E}{R T}\left\{-\ln \left(\frac{W}{W_{0}}\right)\right\}^{1 / n}$

Differentiating equation (8) with respect to $1 / \mathrm{T}$, one can get

$\frac{\partial \ln P}{\partial T}=\frac{\partial}{\partial T} \ln \left(P_{s}\right)+\frac{E}{R T^{2}}\left\{-\ln \left(\frac{W}{W_{0}}\right)\right\}^{1 / n}$

Substituting for isosteric heat of adsorption which is defined by Van't Hoff equation 


$$
\begin{aligned}
& -\frac{Q_{s t}}{R T^{2}}=\frac{\partial}{\partial T} \ln \left(P_{s}\right)+\frac{E}{R T^{2}}\left\{-\ln \left(\frac{W}{W_{0}}\right)\right\}^{1 / n} \\
& -Q_{s t}=R T^{2} \frac{\partial}{\partial T} \ln \left(P_{s}\right)+E\left\{-\ln \left(\frac{W}{W_{0}}\right)\right\}^{1 / n}
\end{aligned}
$$

The $Q_{s t}$ estimated using Eq. (11) is in $(\mathrm{kJ} / \mathrm{kmol})$, however, in this study $Q_{s t}$ is presented in $(\mathrm{kJ} / \mathrm{kg})$ using the molecular weight of the refrigerant.

\section{Results and Discussion}

Figures 3(a)-3(c) show the plots of $\ln (W)$ versus $A^{n}$ of ethanol adsorption onto parent Maxsorb III, KOH- $\mathrm{H}_{2}$ treated Maxsorb III and $\mathrm{H}_{2}$ treated Maxsorb III using the D-A equation, respectively. Employing Eq. (3), one can estimate adsorption isotherm parameters in terms of $n, W_{0}, E$ of the assorted pairs. Their numerical values are furnished in Table 3. Figures 4(a)-4(c) demonstrate a good agreement between the measured value and the predicted value using the theoretical (D-A) adsorption isotherm model. The behavior of these graphs is typical to type I adsorption isotherm in the International Union of Pure and Applied Chemistry (IUPAC) classification [34], which describe monolayer adsorption mechanisms exhibited by microporous adsorbents. The experiments have been carried out across a wide range of adsorption and evaporation temperatures that are useful for adsorption cooling and refrigeration applications. It can be seen from Figs. 4(a)-4(c) that, the adsorption capacity of $\mathrm{H}_{2}$ treated Maxsorb III/ethanol pair is slightly higher than that of parent Maxsorb III/ethanol pair whilst the $\mathrm{KOH}-\mathrm{H}_{2}$ treated Maxsorb III/ethanol possesses the lowest adsorption capacity. This order agrees with the order of the micropores volume of the studied adsorbents which are shown in Table 1 . However, $\mathrm{KOH}-\mathrm{H}_{2}$ treated Maxsorb III/ethanol pair shows 
faster adsorption kinetics compared to the other two studied pairs [24]. This might be due to the hydrogen bonds formed between polar ethanol molecules and the functional groups nearby the adsorbent surface. It is also worthy to mention that, in the present study ethanol of $95 \%$ purity (see Table 2) has been used whilst a high purity ethanol (99.5\%) has been used by El-Sharkawy et al. [11, 24]. Experimental results show that the numerical values of $W_{o}, n$ and $E$ of the assorted pairs using ethanol of $95 \%$ purity is different from those given in the previous studies of some of the authors using ethanol of $99.5 \%$ purity $[11,24]$. This highlights that the refrigerant purity affects the adsorption isotherm parameters of the adsorbent/refrigerant pair.

Figures 5(a)-5(c) show the plots of fractional uptake versus adsorption potential for parent Maxsorb III/ethanol, $\mathrm{KOH}-\mathrm{H}_{2}$ treated Maxsorb III/ethanol and $\mathrm{H}_{2}$ treated Maxsorb III/ethanol pairs. These figures show that characteristic energy is temperature-independent and the adsorption proceeds according to the D-A isotherm model. On the basis of the adsorption characteristic curve, the adsorption isotherm for any temperature can be drawn [35].

Plots of the adsorption potential versus the relative pressure are shown in Figs. 6(a)-6(c). It is shown from these figures that at low relative pressure the adsorption potential is quite high, while it is low for high relative pressure which means that at higher relative pressure less molar work is required for adsorption via micropore filling when the gas is approaching the vapor pressure.

The isosteric heat of adsorption is calculated using the Clausius-Clapeyron equation by means of equilibrium adsorption data which are shown in Figs. 7(a)-7(c). Data presented in these figures are generated from direct pressure and temperature measurements during adsorption. All experimental data yielded straight lines with regression coefficients $>99.9 \%$. The slopes of the line yield the value of $Q_{s} / R$. The average values of isosteric heats of adsorption for parent Maxsorb III, $\mathrm{KOH}-\mathrm{H}_{2}$ treated Maxsorb III and $\mathrm{H}_{2}$ treated Maxsorb III with ethanol pairs are found to be 1002, 963 and $926 \mathrm{~kJ} / \mathrm{kg}$, respectively. 
Figures 8(a)-8(c) show the concentration dependance of isosteric heat of adsorption at constant temperature using Eq. (11). It can be seen from Figures 8(a)-8(c) that the isosteric heat of adsorption decreases with increasing adsorbate uptake which reveals the heterogenous adsorbents characteristics with a wide range of gas-solid interaction energies [36]. As the molecules first penetrate into the narrower micropores, which results in a stronger interaction between adsorbate and assorted adsorbents. This implies a higher value of isosteric heat of adsorption at the beginning of the adsorption. After that molecules are gradually accumulated in larger pores, which means the adsorption affinity becomes weaker in higher uptake region. Therefore the graph shows a monotonic decrease in isosteric heat of adsorption as a function of uptake and finally approaches towards latent heat of evaporation [37].

Figure 9 shows the percentage of deviation of isosteric heat values from its average value for Maxsorb III/ethanol pair. The isosteric heat data are calculated using Eq. (11) for adsorption temperatures of 30, 50 and $70{ }^{\circ} \mathrm{C}$. The deviation is found to be within $\pm 10 \%$ over the whole range of fractional uptake. It can be noted here that one should consider the isosteric heat data as a function of relative pressure for evaluating the adsorption system performance precisely.

\section{CONCLUSIONS}

Adsorption isotherms of parent Maxsorb III/ethanol, $\mathrm{KOH}-\mathrm{H}_{2}$ treated Maxsorb III/ethanol and $\mathrm{H}_{2}$ treated Maxsorb III/ethanol pairs have been experimentally measured using a magnetic suspension adsorption measurement unit. Experiments have been conducted within evaporation temperature ranges from -14 to $77^{\circ} \mathrm{C}$ and adsorption temperatures between 20 and $80{ }^{\circ} \mathrm{C}$. The data have been correlated using the Dubinin-Astakhov isotherm model. Effect of the refrigerant purity on the adsorption characteristics of the adsorbent/refrigerant pair is also discussed. Experimental results show that, adsorption capacity of $\mathrm{H}_{2}$ treated Maxsorb III/ethanol is slightly higher than that of the parent Maxsorb 
III/ethanol pair whilst the $\mathrm{KOH}-\mathrm{H}_{2}$ treated Maxsorb III has the lowest adsorption capacity. However, $\mathrm{KOH}-\mathrm{H}_{2}$ treated Maxsorb III/ethanol pair shows faster adsorption kinetics compared to the other two studied pairs. The isosteric heats of adsorption of assorted adsorbent/refrigerant pairs are also evaluated from the experiment data using Clausius-Clapeyron and D-A equations. It is found that, the average heats of adsorption of ethanol onto parent Maxsorb III, $\mathrm{KOH}-\mathrm{H}_{2}$ treated Maxsorb III and $\mathrm{H}_{2}$ treated Maxsorb III is found to be 1002,963 and $926 \mathrm{~kJ} / \mathrm{kg}$, respectively.

\section{ACKNOWLEDGEMENTS}

This work was financially supported by Japan Science and Technology Agency (JST), Core Research for Evolutional Science and Technology (CREST). 


\section{REFERENCES}

[1] E.C. Boelman, B.B. Saha, T. Kashiwagi, Experimental investigation of a silica gel-water adsorption refrigeration cycle- the influence of operating conditions on cooling output and COP, ASHRAE Trans. Res. 101(2) (1995) pp. 358-366.

[2] A. Chakraborty, B.B. Saha, S. Koyama, K.C. Ng, K. Srinivasan, Adsorption thermodynamics of silica gel-water systems, J. Chem. Eng. Data 54 (2009) pp. 448-452.

[3] T. Miyazaki, A. Akisawa, B.B. Saha, I.I. El-Sharkawy, A. Chakraborty, A new cycle time allocation for enhancing the performance of two-bed adsorption chillers, Int. J. Refrig. 32 (2009) pp. 846-853.

[4] Y. Liu, K.C. Leong, The effect of operating conditions on the performance of zeolite/water adsorption cooling systems, Appl. Therm. Eng. 25 (2005) pp.1403-1418.

[5] G.H.W. van Benethem, G. Cacciola, G. Restuccia, Regenerative adsorption heat pumps: Optimization of the design, Heat Recovery. Syst. CHP 15(6) (1995) pp. 531-544.

[6] Z. T.-Telto, S.J. Metcalf, R.E. Critoph, Y. Zhong, R. Thrope, Carbon-ammonia pairs for adsorption refrigeration applications: ice making, air conditioning and heat pumping, Int. J. Refrig. 32 (2009) pp. 1212-1229.

[7] M. Li, H.B. Huang, R.Z. Wang, L.L. Wang, W.D. Cai, W.M. Yang, Experimental study on adsorbent of activated carbon with refrigerant of methanol and ethanol for solar ice maker, Renewable Energy 29 (2004) pp. 2235-2244.

[8] I.I. El-Sharkawy, M. Hassan, B.B. Saha, S. Koyama, M.M. Nasr, Study on adsorption of methanol onto activated carbon based adsorbents, Int. J. Refrig. 32 (2009) pp. 1579-1586.

[9] L.W. Wang, J.Y. Wu, R.Z. Wang, Y.X. Xu, S.G. Wang, Experimental study of a solidified activated carbon methanol adsorption ice maker, Appl. Therm. Eng. 23 (2003) pp. 1453-1462. 
[10] I.I. El-Sharkawy, K. Kuwahara, B.B. Saha, S. Koyama, K.C. Ng, Experimental investigation of activated carbon fibers/ethanol pairs for adsorption cooling systems application, Appl. Therm. Eng. 26 (8-9), (2006) pp. 859-865.

[11] I.I. El-Sharkawy, B.B. Saha, S. Koyama, J. He, K.C. Ng, C. Yap, Experimental investigation on activated carbon-ethanol pair for solar powered adsorption cooling applications, Int. J. Refrig. 31 (2008) pp. 1407-1413.

[12] M.A. Sheikh, M.M.I. Hasan, K.F. Laughlin, Adsorption equilibria and rate parameters for nitrogen and methane on Maxsorb activated carbon, Gas Sep. Purif. 10 (1996) pp. 161-168.

[13] S. Himeno, T. Komatsu, S. Fujita, High pressure adsorption equilibria of methane and carbon dioxide on several activated carbons, J. Chem. Eng. Data 50 (2005) pp. 369-376.

[14] J. Alcaniz-Monge, M.A. De La Casa-Lillo, D. Cazorla-Amoros, A. Linares-Solano, Methane storage in activated carbon fibers, Carbon 35 (1997) pp. 291-297.

[15] M.M.K. Salem, P. Braeuer, M.V. Szombathely, M. Heuchel, P. Harting, K. Quitzsch, M. Jaroniec, Thermodynamics of high-pressure adsorption of argon, nitrogen, and methane on microporous adsorbents, Langmuir 14 (1998) pp. 3376-3389.

[16] M.D. Hornbostel, J. Bao, G. Krishnan, A. Nagar, I. Jayaweera, T. Kobayashi, A. Sanjurjo, J. Sweeney, D. Carruthers, M.A. Petruska, L. Dubois, Characteristics of an advanced carbon sorbent for $\mathrm{CO}_{2}$ capture, Carbon 56 (2013) pp. 77-85.

[17] B.B. Saha, I.I. El-Sharkawy, R. Thorpe, R.E. Critoph, Accurate adsorption isotherms of R134a onto activated carbons for cooling and freezing applications, Int. J. Refrig. 35 (2012) pp. 499-505.

[18] S.K. Henninger, F.P. Schmidt, H.-M. Henning, Water adsorption characteristics of novel material for heat transformation applications, Appl. Therm. Eng. 30 (2010) pp. 1692-1702.

[19] E. Glueckauf, J.I. Coats, Theory of chromatography. Part IV. The influence of incomplete equilibrium on the front boundary of chromatograms and the effectiveness of separation, J. Chem. 
Soc. (1947) pp. 1315-1321.

[20] W.S. Loh, M. Kumja, K.A. Rahman, K.C. Ng, B.B. Saha, S. Koyama, I.I, El-Sharkawy, Adsorption parameter and heat of adsorption of activated carbon/HFC-R134a pair, Heat Transfer Eng. 31 (11) (2010) pp. 910-916.

[21] B.B. Saha, S. Jribi, S. Koyama, I.I. El-Sharkawy, Carbon dioxide adsorption isotherms on activated carbons, J. Chem. Eng. Data 56 (2011) pp. 1974-1981.

[22] B.B. Saha, S. Koyama, I.I. El-Sharkawy, K. Habib, K. Srinivasan, P. Dutta, Evaluation of adsorption parameters and heats of adsorption through desorption measurements, J. Chem. Eng. Data 52, (2007) pp. 2419-2424.

[23] H.S. Kil, K. Hata, K. Ideta, J. Miyawaki, I. Mochida, S.H. Yoon, Influence of surface functionality on ethanol adsorption behavior in activated carbons analyzed by solid-state NMR, in: B.B. Saha et al. (Ed.), Proceeding of Innovative Materials for Processes in Energy Systems 2013 (IMPRES2013), Fukuoka, Japan, 2013, pp. 525-528.

[24] I. I. El-Sharkawy, K. Uddin, T. Miyazaki, B. B. Saha, S. Koyama, J. Miyawaki, S.H. Yoon, Adsorption of ethanol onto parent and surface treated activated carbon powders, Int. J. Heat Mass Transfer 73, (2014) pp. 445-455.

[25] Magnetic suspension balances, www.rubotherm.com

[26] M.M. Dubinin, Adsorption in micropores, J. Colloid Interface Sci. 23 (1961) pp. 487-499.

[27] M.M. Dubinin, V.A. Astakhov, Development of the concepts of volume filling of micropores in the adsorption of gases and vapors by microporous adsorbents, Bulletin of the academy of sciences of the USSR 20 (1971) pp.3-7.

[28] J. Szekely, J.W. Evans, H.Y. Sohn, Gas-solid Reaction. Academic Press, New York (1976).

[29] S. Agnihotri, M.J. Tood, M. Rostam-Abadi, Adsorption equilibrium of organic vapors on singlewalled carbon nanotubes, Carbon 43 (2005) pp.2490-2493. 
[30] A. Chakraborty, B.B. Saha, S. Koyama, K.C. Ng, On the thermodynamic modeling of the isosteric heat of adsorption and comparison with experiments, Appl. Phys. Lett. 89 (2006) 171901.

[31] I. I. El-Sharkawy, B.B. Saha, S. Koyama, K. Srinivasan, Isosteric heat of adsorption extracted from experiments of ethanol and HFC 134a on carbon based adsorbents, Int. J. Heat Mass Transfer 50 (2007) pp. 902-907.

[32] D. Shen, M. Bülow, Comparison of experimental techniques for measuring isosteric heat of adsorption, Adsorption 6 (2000) pp. 275-286.

[33] Do, D. D., Adsorption Analysis: Equilibria and Kinetics, Series on Chem. Eng. Vol. 2, Imperial College Press, London (1998).

[34] S. Brunauer, L.S. Deming, W.E. Deming, E.Teller, On a theory of the van der Waals adsorption of gases, J. Am. Chem. Soc. 62 (1940) pp. 1723-1732.

[35] I.A.A.C. Esteves, M.S.S. Lopes, P.M.C. Nunes, J.P.B. Mota, Adsorption of natural gas and biogas components on activated carbon, Sep. Purif. Technol. 62 (2008) pp. 281-296.

[36] J.A. Dunne, R. Mariwala, M. Rao, S. Sircar, R.J. Gorte, A.L. Myers, Calorimetric heats of adsorption and adsorption isotherms. 1. $\mathrm{CO}_{2}, \mathrm{~N}_{2}, \mathrm{Ar}, \mathrm{CO}_{2}, \mathrm{C}_{2} \mathrm{H}_{6}$, and $\mathrm{SF}_{6}$ on silicate, Langmuir 12 (1996) pp.5888-5895.

[37] B.B. Saha, K. Habib, I.I. El-Sharkawy, S. Koyama, Adsorption characteristics and heat of adsorption measurements on R-134a on activated carbon, Int. J. Refrig. 32 (2009) pp. 1563-1569. 


\section{List of Figures}

Fig. 1. SEM pictures of the studied adsorbents (a) parent Maxsorb III, (b) $\mathrm{H}_{2}$ treated Maxsorb III and (c) $\mathrm{KOH}-\mathrm{H}_{2}$ treated Maxsorb III.

Fig. 2. Schematic of the magnetic suspension balance section.

Fig. 3(a). Linear fitting of D-A equation for parent Maxsorb III/ethanol pair.

Fig. 3(b). Linear fitting of D-A equation for $\mathrm{KOH}-\mathrm{H}_{2}$ treated Maxsorb III/ethanol pair.

Fig. 3(c). Linear fitting of D-A equation for $\mathrm{H}_{2}$ treated Maxsorb III/ethanol pair.

Fig. 4(a). Adsorption isotherms of parent Maxsorb III/ethanol pair.

Fig. 4(b). Adsorption isotherms of $\mathrm{KOH}-\mathrm{H}_{2}$ treated Maxsorb III/ethanol pair.

Fig. 4(c). Adsorption isotherms of $\mathrm{H}_{2}$ treated Maxsorb III/ethanol pair.

Fig. 5(a). Plot of fractional uptake versus adsorption potential for parent Maxsorb III/ethanol pair.

Fig. 5(b). Plot of fractional uptake versus adsorption potential for $\mathrm{KOH}-\mathrm{H}_{2}$ treated Maxsorb III/ethanol pair.

Fig. 5(c). Plot of fractional uptake versus adsorption potential for $\mathrm{H}_{2}$ treated Maxsorb III/ethanol pair.

Fig. 6(a). Plot of the adsorption potential versus relative pressure for parent Maxsorb III/ethanol pair.

Fig. 6(b). Plot of the adsorption potential versus relative pressure for $\mathrm{KOH}-\mathrm{H}_{2}$ treated Maxsorb III/ethanol pair.

Fig. 6(c). Plot of the adsorption potential versus relative pressure for $\mathrm{H}_{2}$ treated Maxsorb III/ethanol pair

Fig. 7(a). Plot of $\ln (P)$ vs $1 / T$ at different uptake range for parent Maxsorb III/ethanol pair.

Fig. 7(b). Plot of $\ln (P)$ vs $1 / T$ at different uptake range for $\mathrm{KOH}-\mathrm{H}_{2}$ treated Maxsorb III/ethanol pair.

Fig. 7(c). Plot of $\ln (P)$ vs $1 / T$ at different uptake range for $\mathrm{H}_{2}$ treated Maxsorb III/ethanol pair.

Fig. 8(a). Isosteric heat of adsorption of ethanol onto parent Maxsorb III/ethanol pair.

Fig. 8(b). Isosteric heat of adsorption of ethanol onto $\mathrm{KOH}-\mathrm{H}_{2}$ treated Maxsorb III/ethanol pair. 
Fig. 8(c). Isosteric heat of adsorption of ethanol onto $\mathrm{H}_{2}$ treated Maxsorb III/ethanol pair.

Fig. 9. Percentage of deviation of isosteric heat from its average value for parent Maxsorb III/ethanol pair. 
Figures
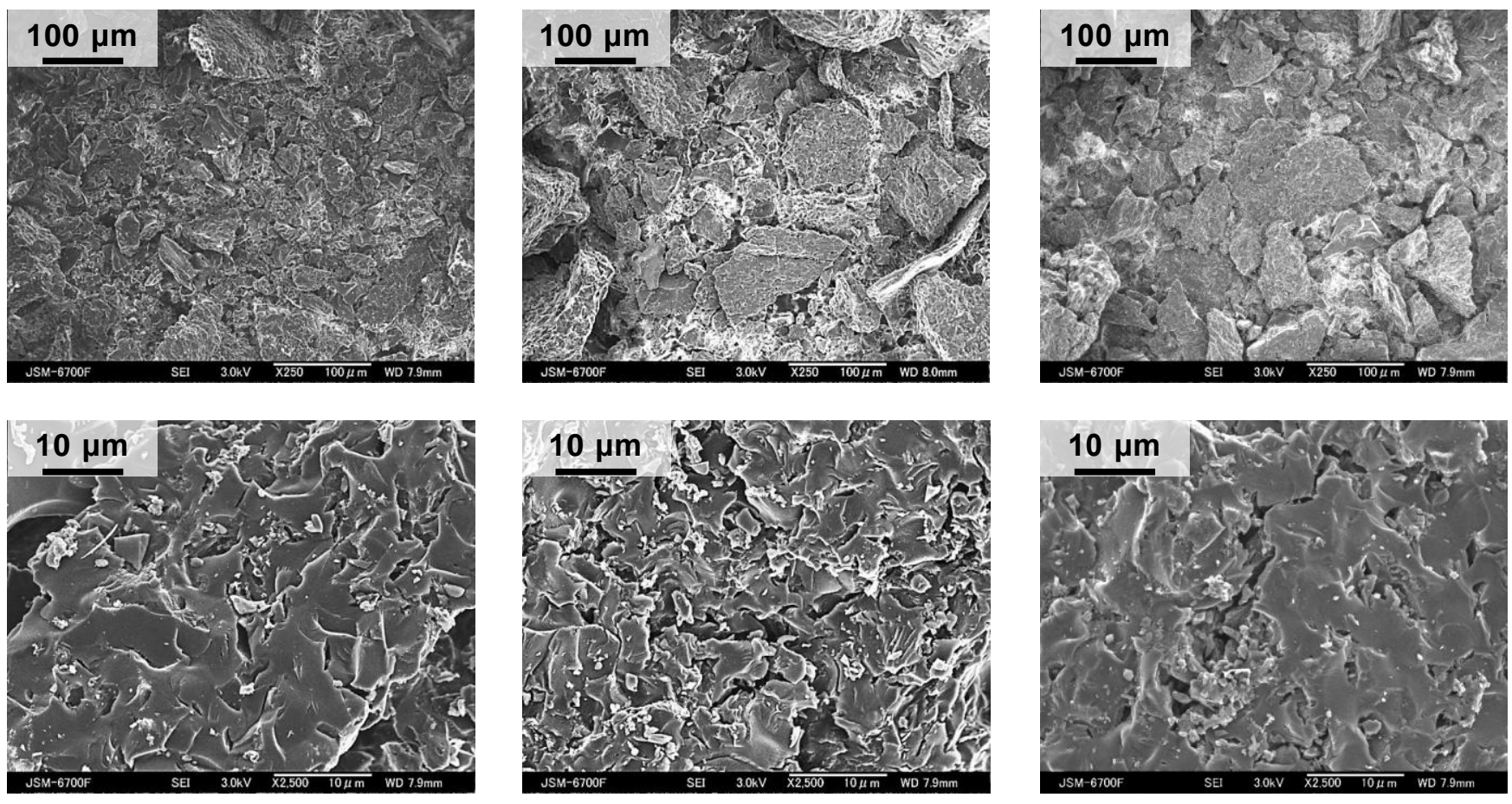

(a)

(b)

(c)

Fig. 1. SEM pictures of the studied adsorbents (a) parent Maxsorb III, (b) $\mathrm{H}_{2}$ treated Maxsorb III and (c) $\mathrm{KOH}-\mathrm{H}_{2}$ treated Maxsorb III. 


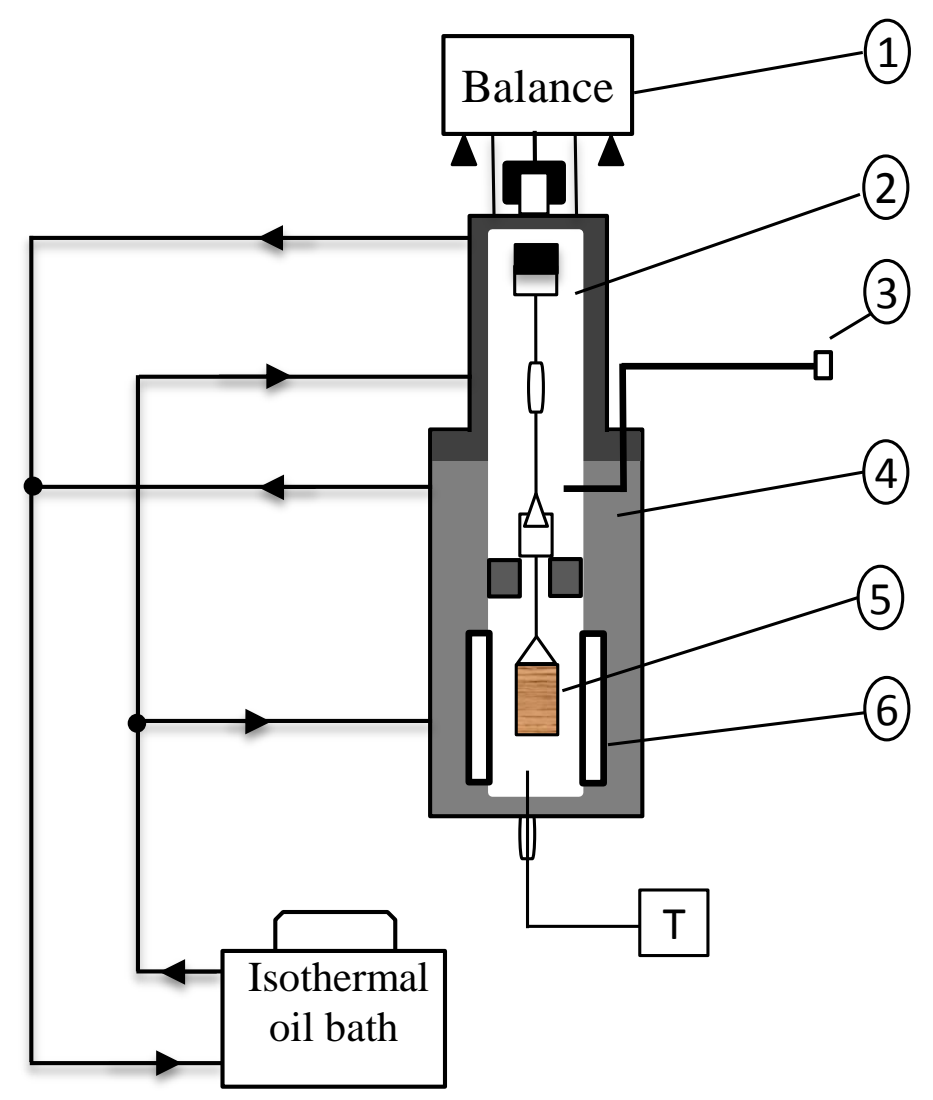

Fig. 2. Schematic of the magnetic suspension balance section.

1. Balance for measuring the weight of the sample, 2. Magnetic coupling section, 3. Port to connect evaporator and vacuum pump, 4. Isothermal oil jacket, 5. Sample cell, 6. Sheathed heater, T. thermocouple 


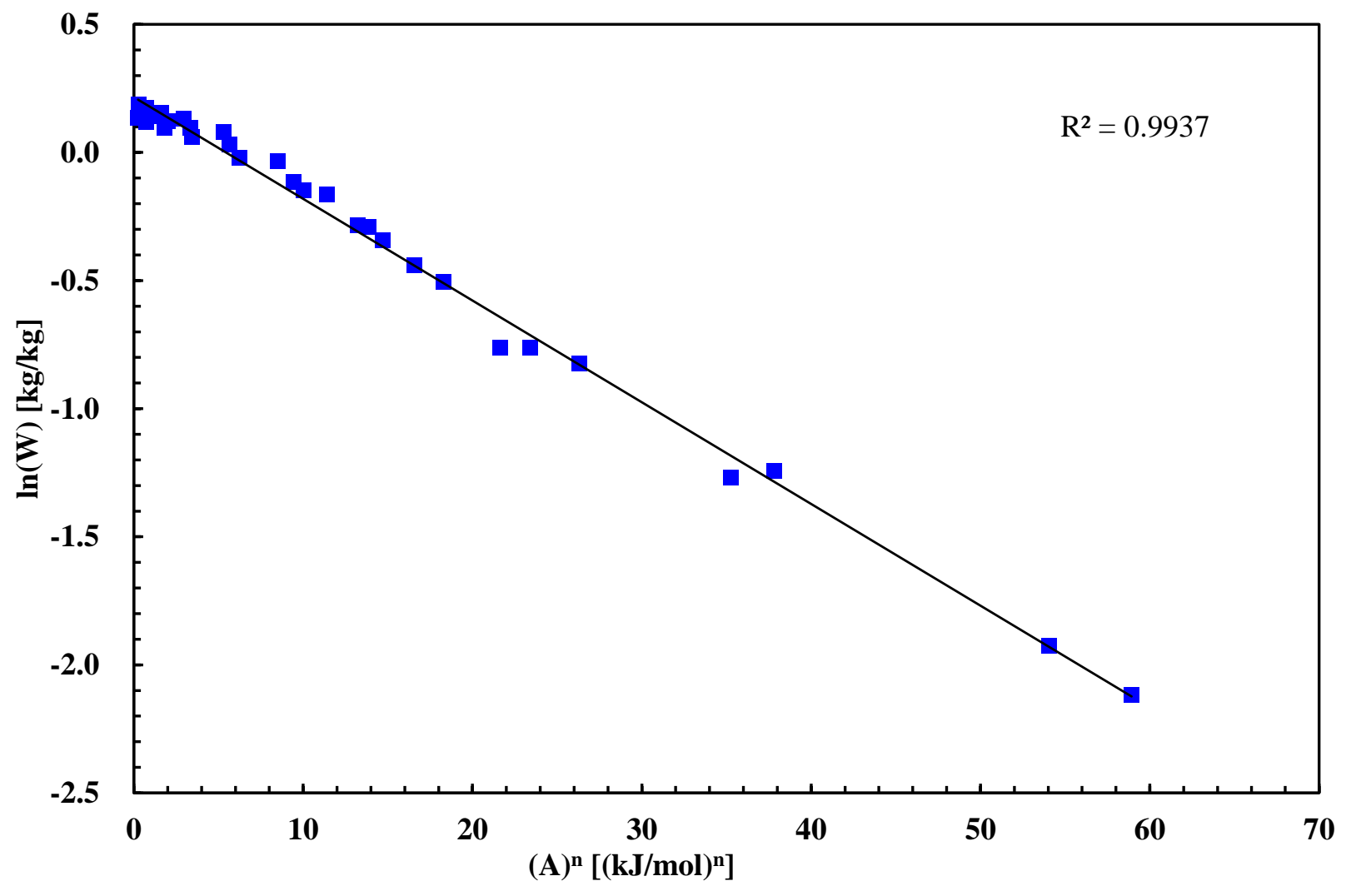

Fig. 3(a). Linear fitting of D-A equation for parent Maxsorb III/ethanol pair. 


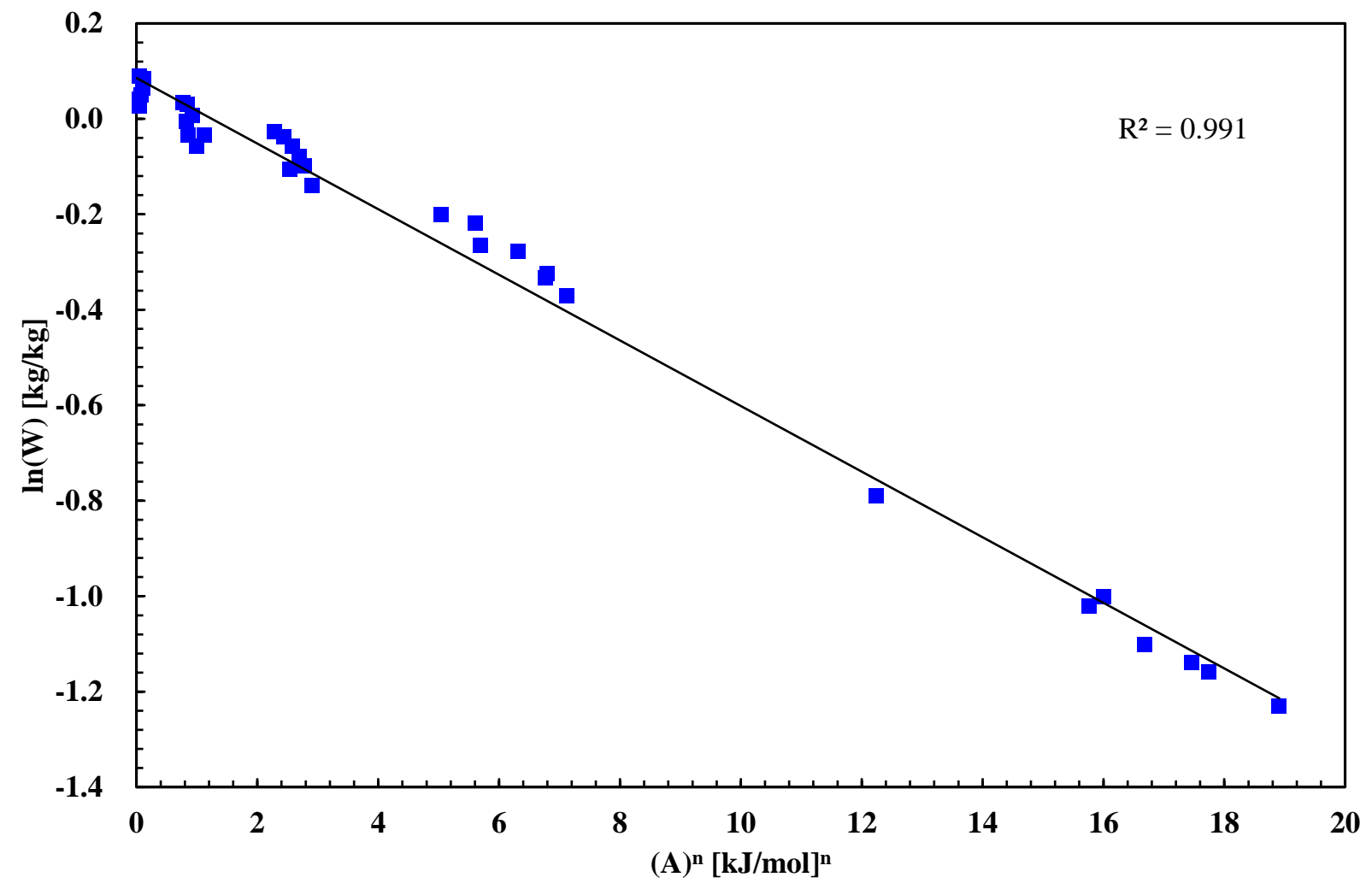

Fig. 3(b). Linear fitting of D-A equation for $\mathrm{KOH}-\mathrm{H}_{2}$ treated Maxsorb III/ethanol pair. 


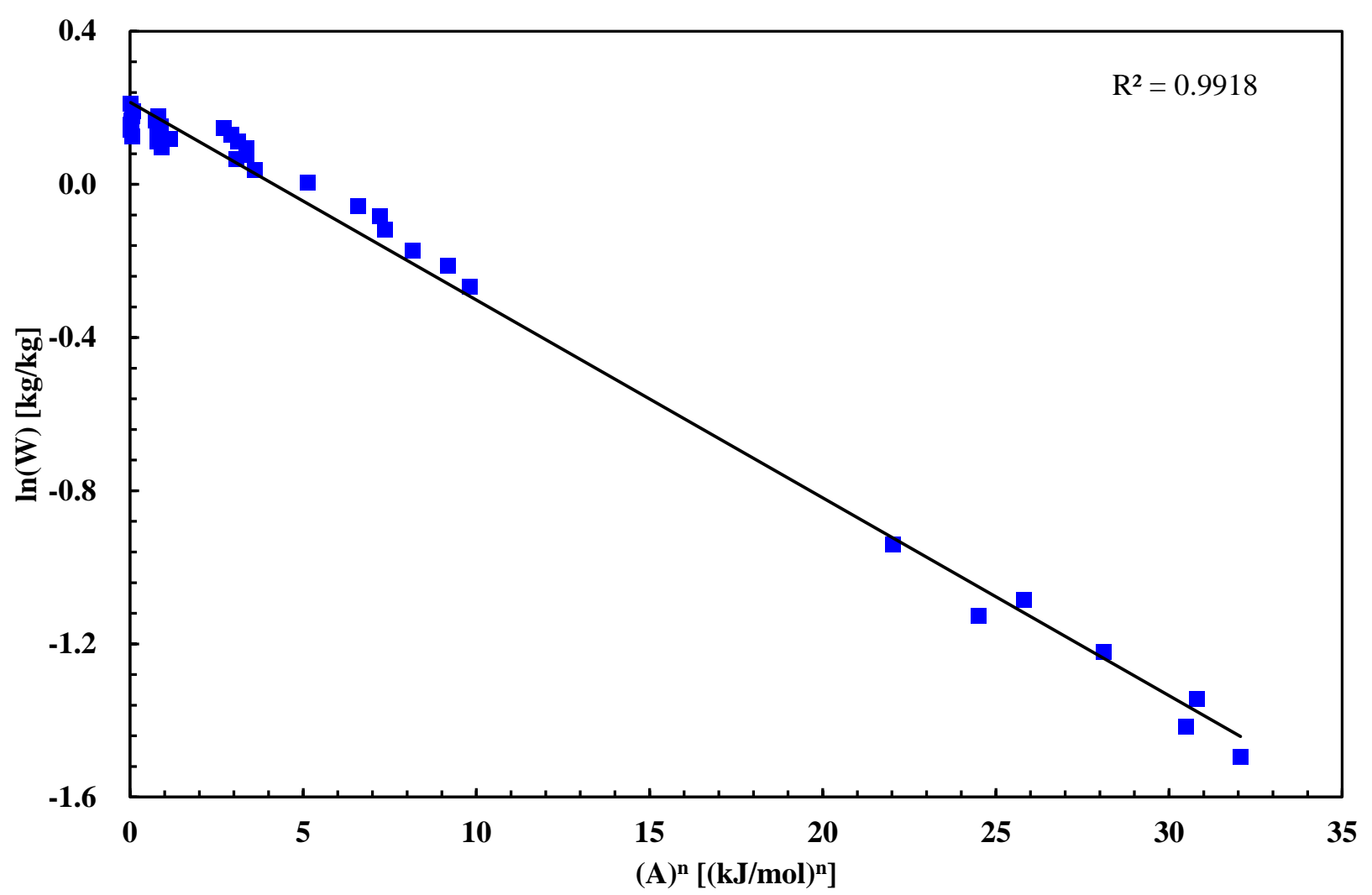

Fig. 3(c). Linear fitting of D-A equation for $\mathrm{H}_{2}$ treated Maxsorb III/ethanol pair. 


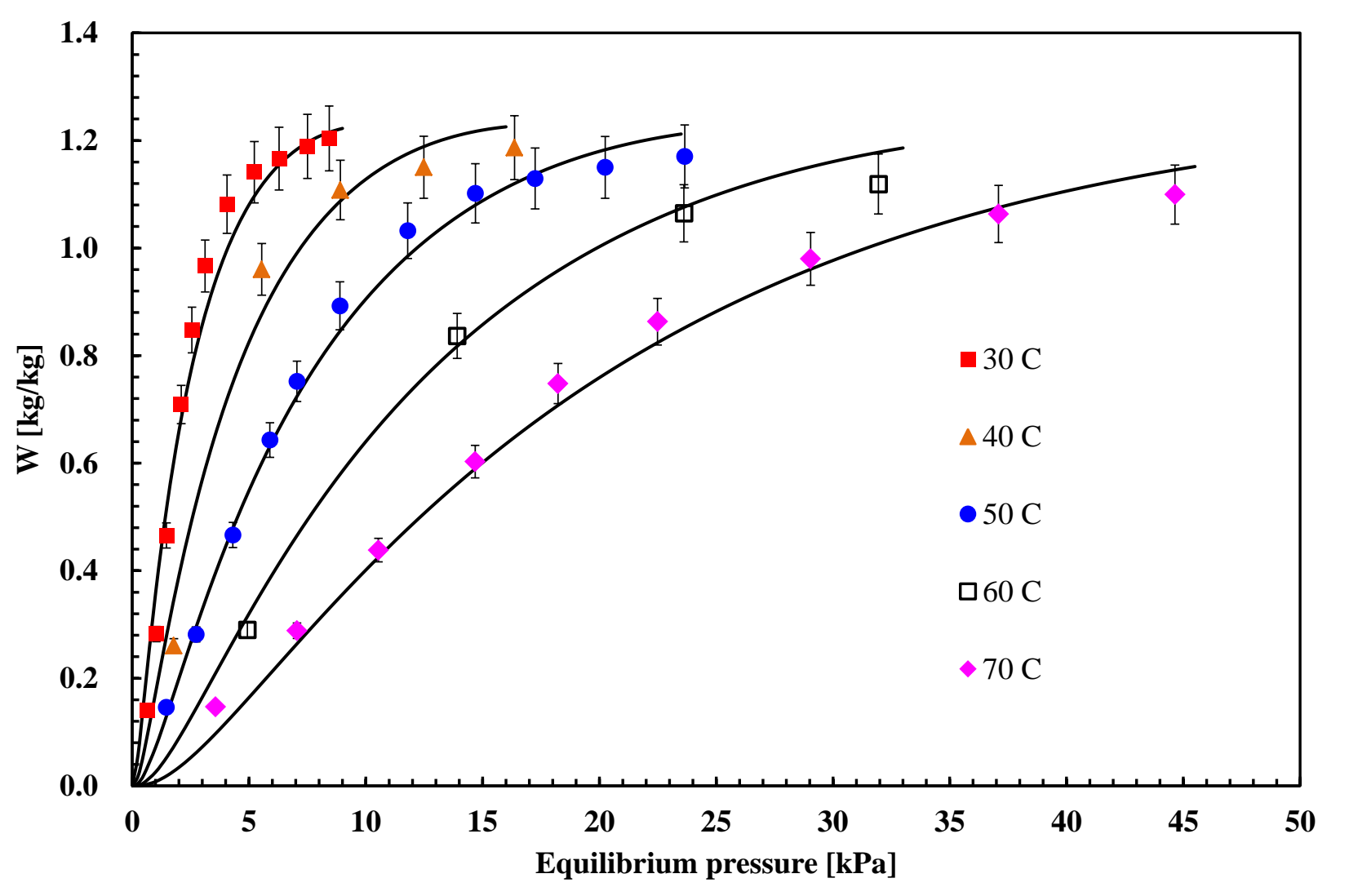

Fig. 4(a). Adsorption isotherms of parent Maxsorb III/ethanol pair. 


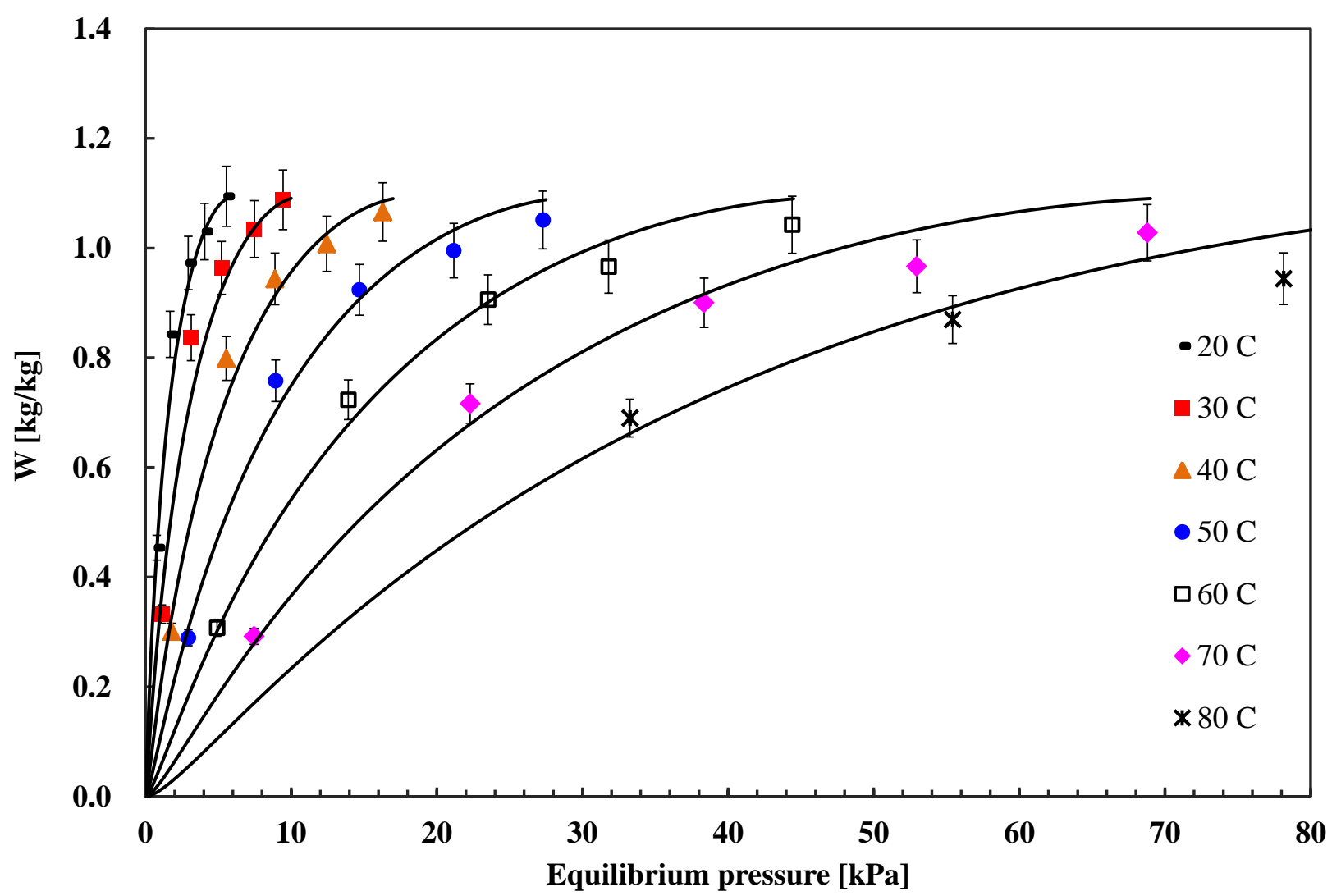

Fig. 4(b). Adsorption isotherms of $\mathrm{KOH}-\mathrm{H}_{2}$ treated Maxsorb III/ethanol pair. 


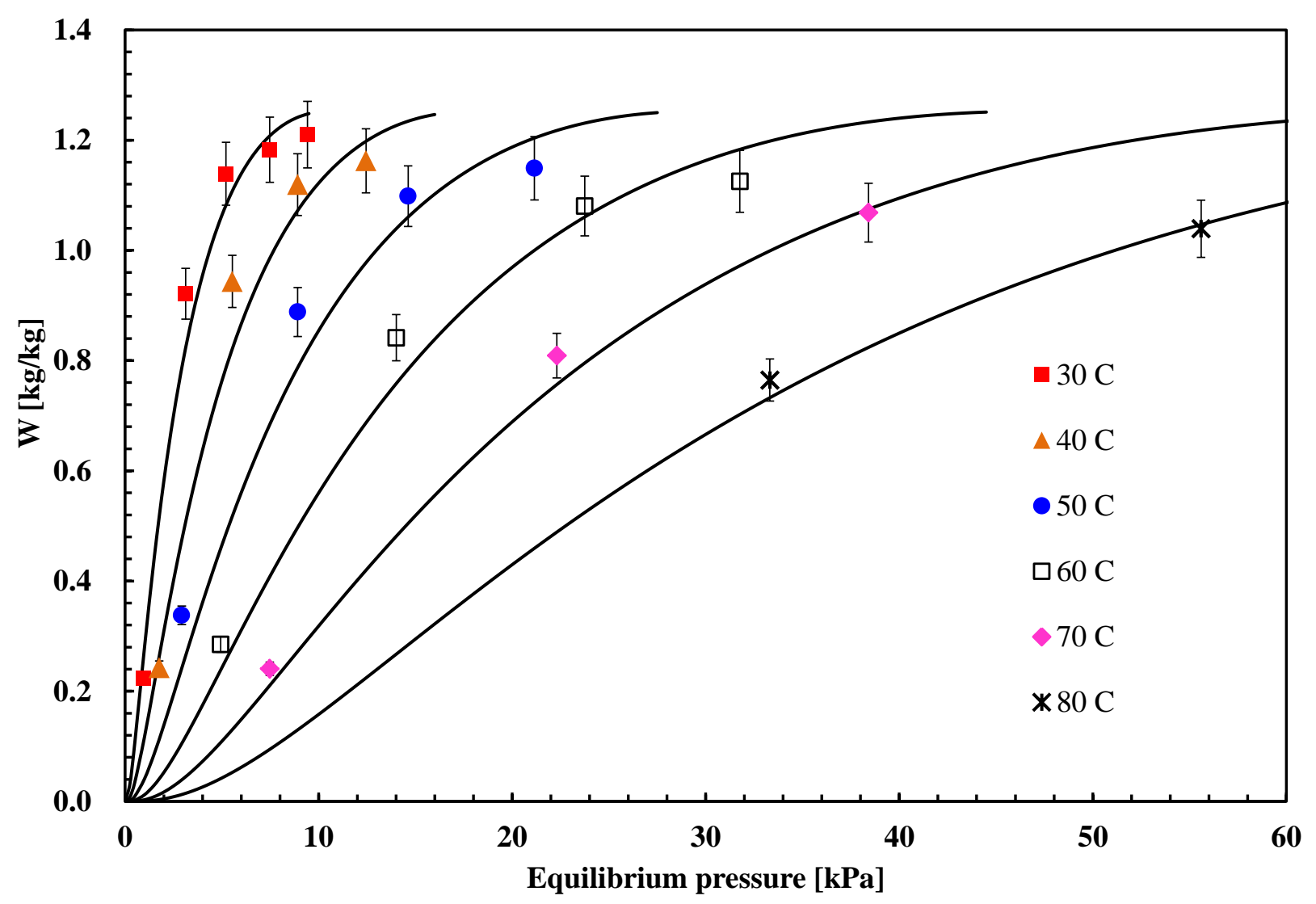

Fig. 4(c). Adsorption isotherms of $\mathrm{H}_{2}$ treated Maxsorb III/ethanol pair. 


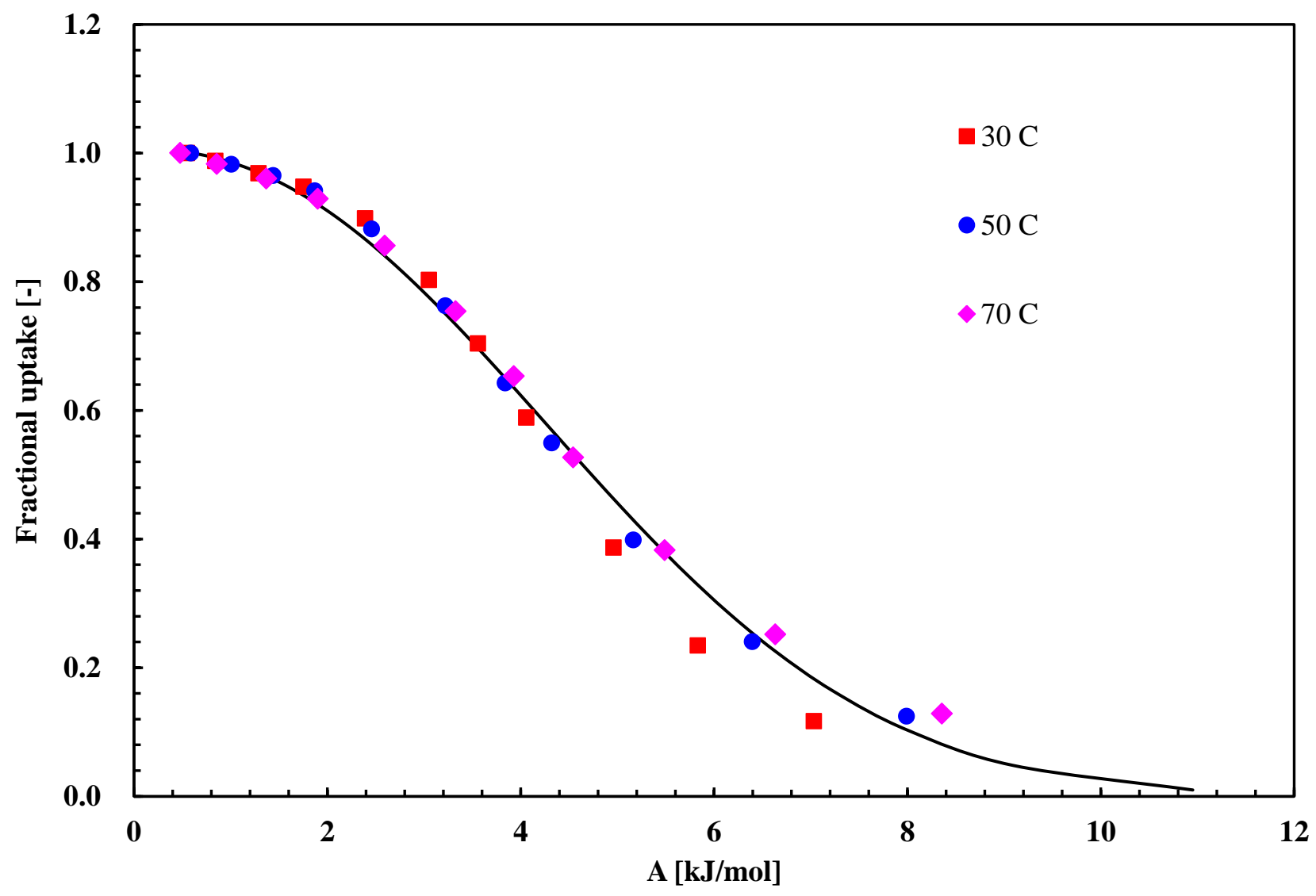

Fig. 5(a). Plot of fractional uptake versus adsorption potential for parent Maxsorb III/ethanol pair. 


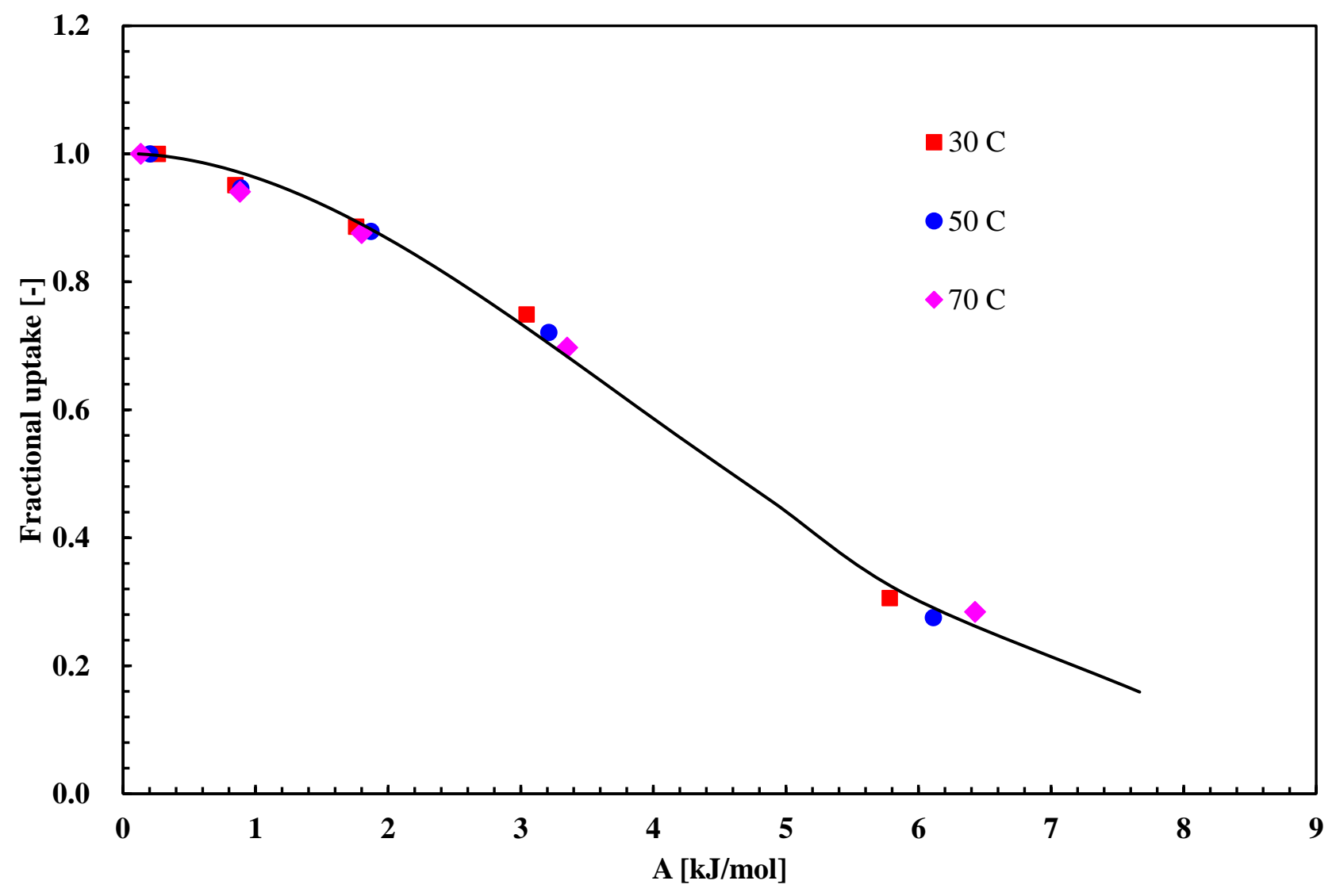

Fig. 5(b). Plot of fractional uptake versus adsorption potential for $\mathrm{KOH}-\mathrm{H}_{2}$ treated Maxsorb III/ethanol pair. 


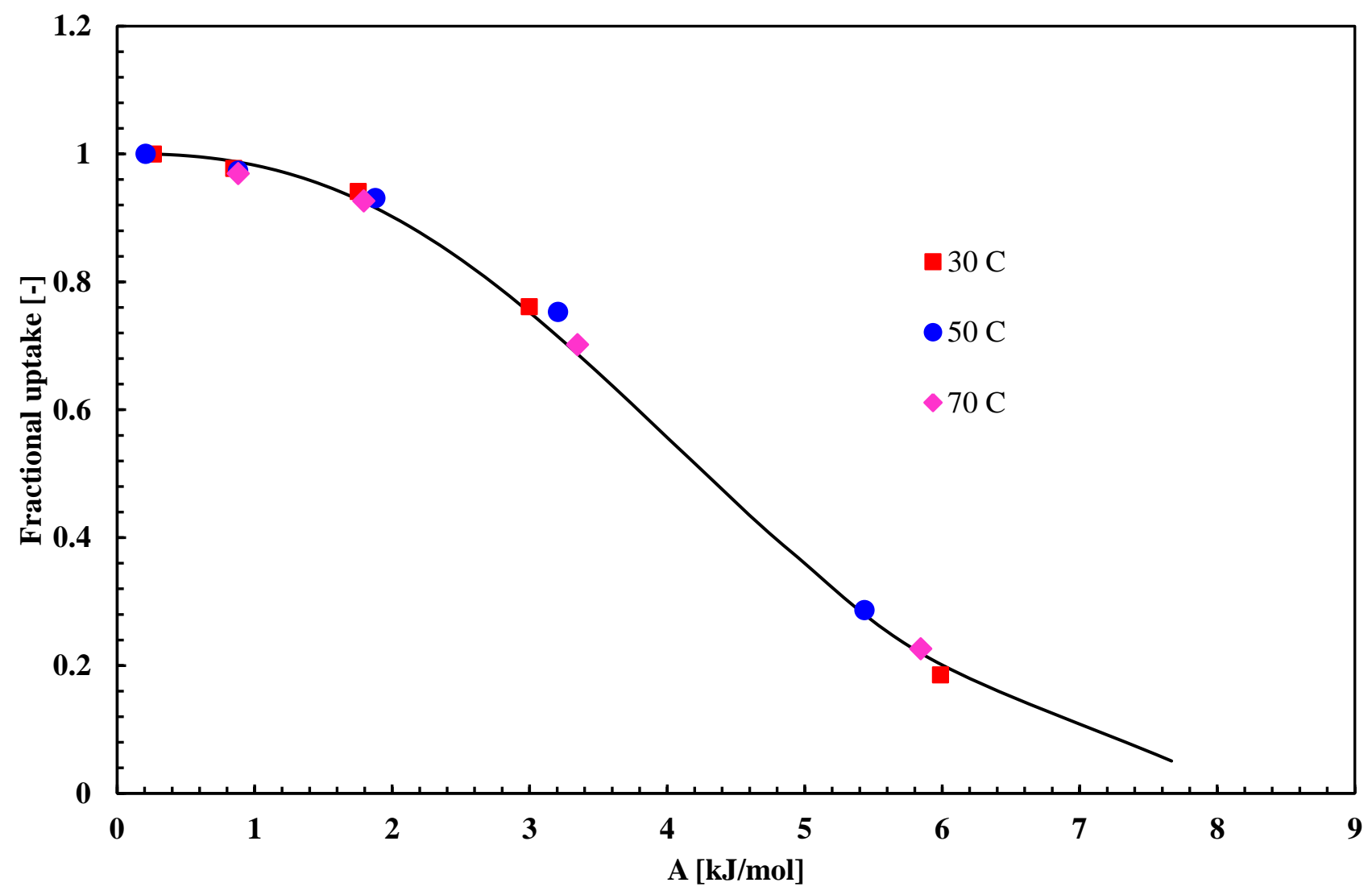

Fig. 5(c). Plot of fractional uptake versus adsorption potential for $\mathrm{H}_{2}$ treated Maxsorb III/ethanol pair. 


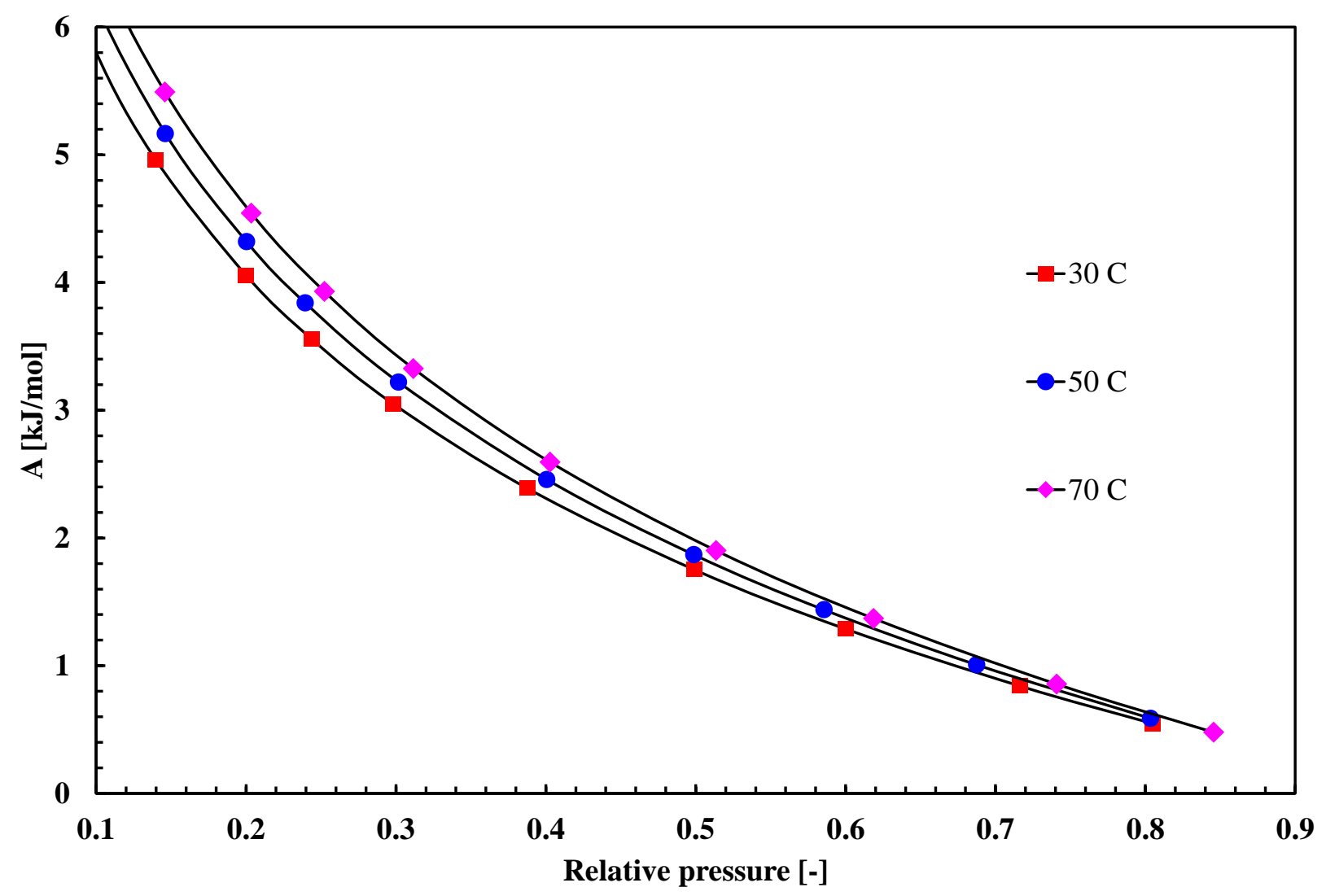

Fig. 6(a). Plot of the adsorption potential versus relative pressure for parent Maxsorb III/ethanol pair. 


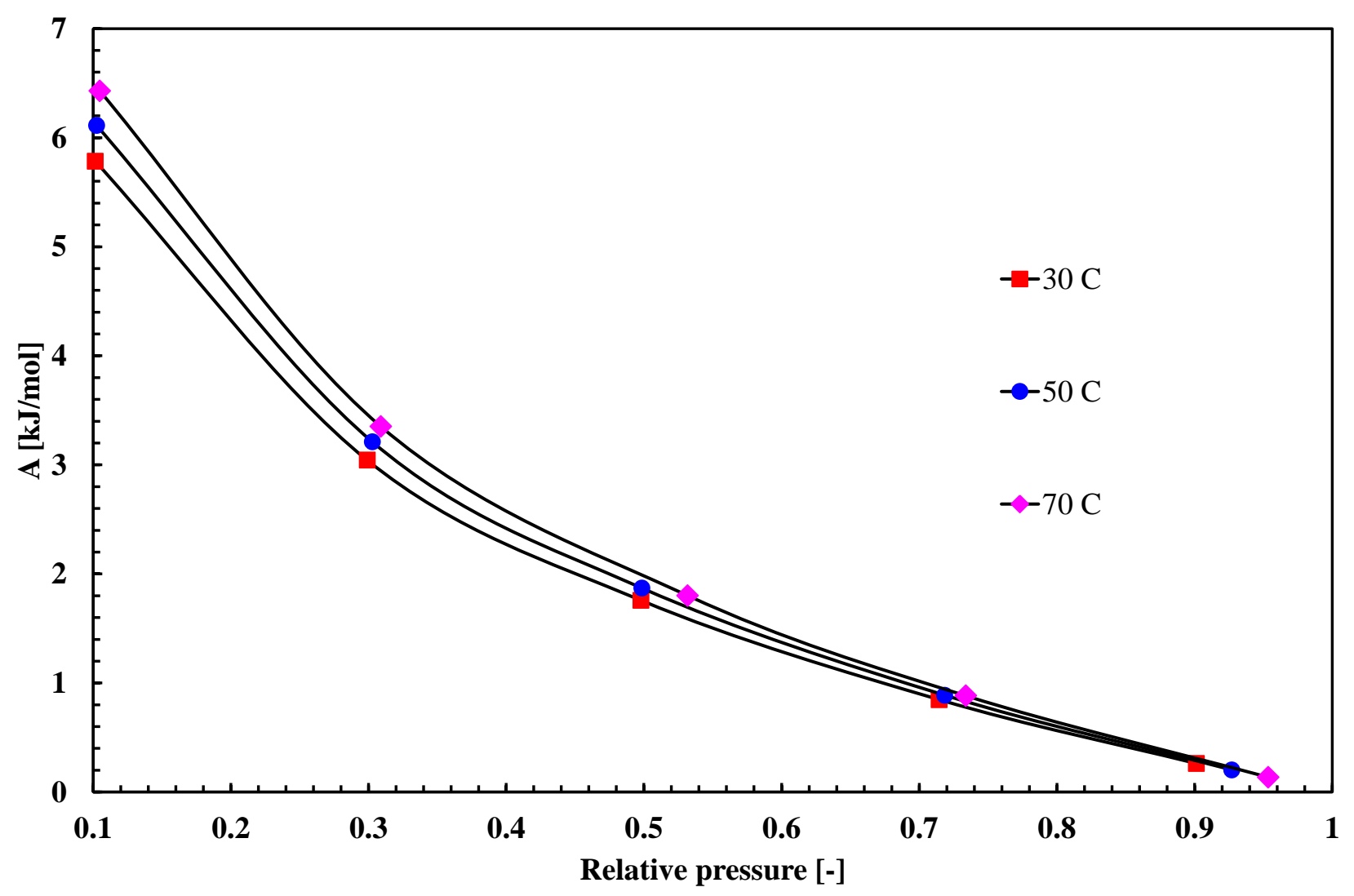

Fig. 6(b). Plot of the adsorption potential versus relative pressure for $\mathrm{KOH}-\mathrm{H}_{2}$ treated Maxsorb III/ethanol pair. 


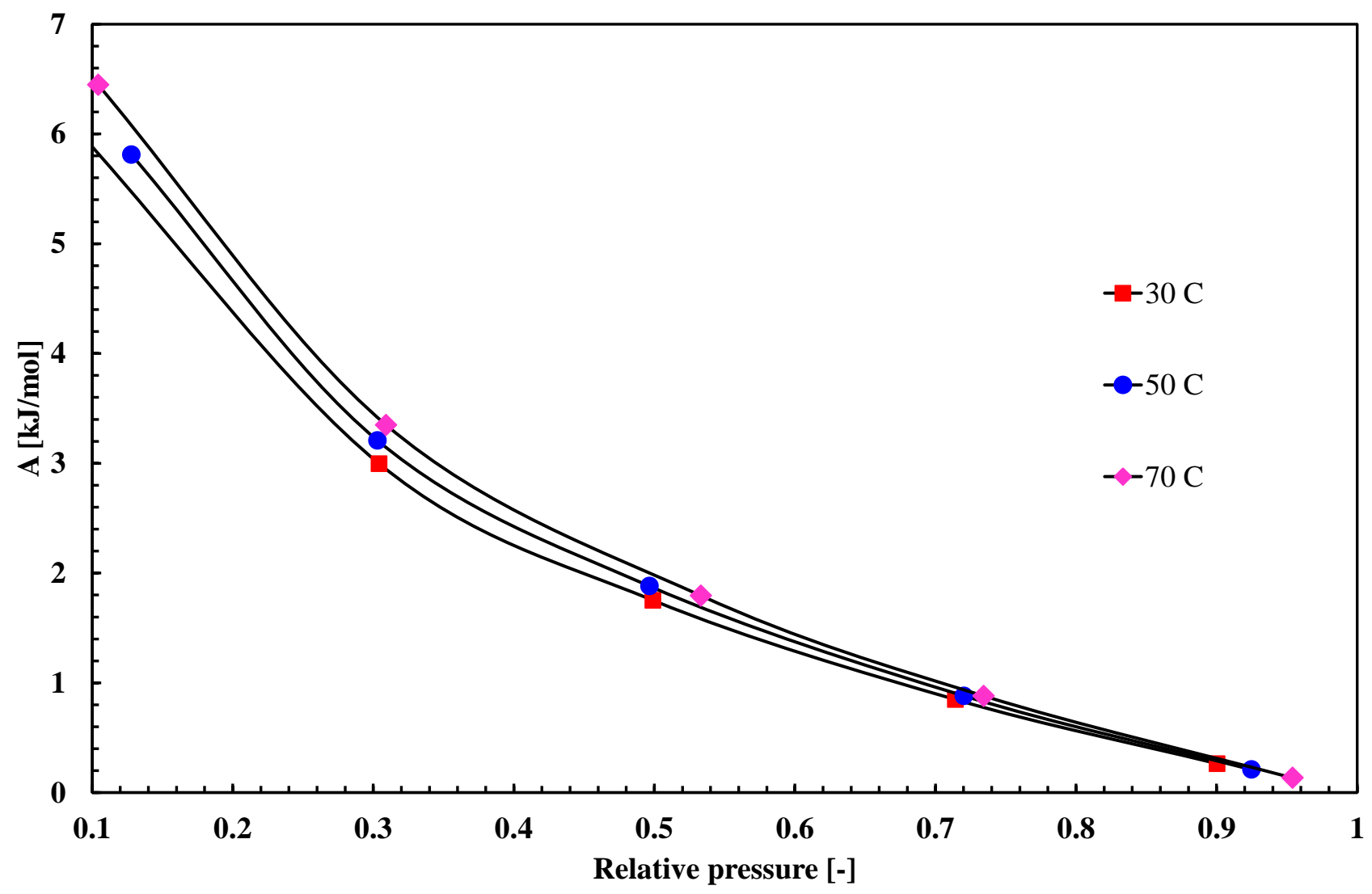

Fig. 6(c). Plot of the adsorption potential versus relative pressure for $\mathrm{H}_{2}$ treated Maxsorb III/ethanol pair. 


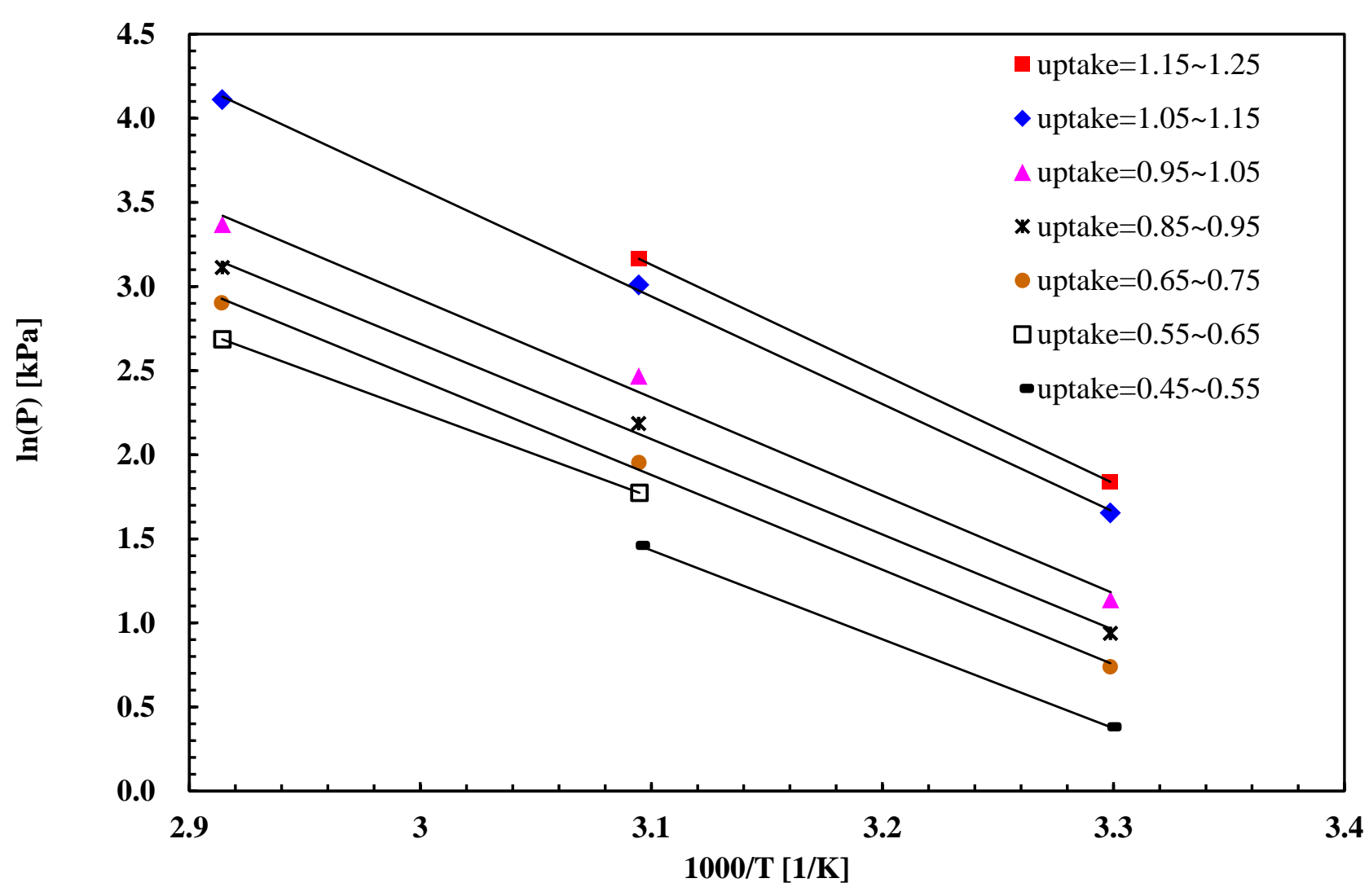

Fig. 7(a). Plot of $\ln (P)$ vs $1 / T$ at different uptake range for parent Maxsorb III/ethanol pair. 


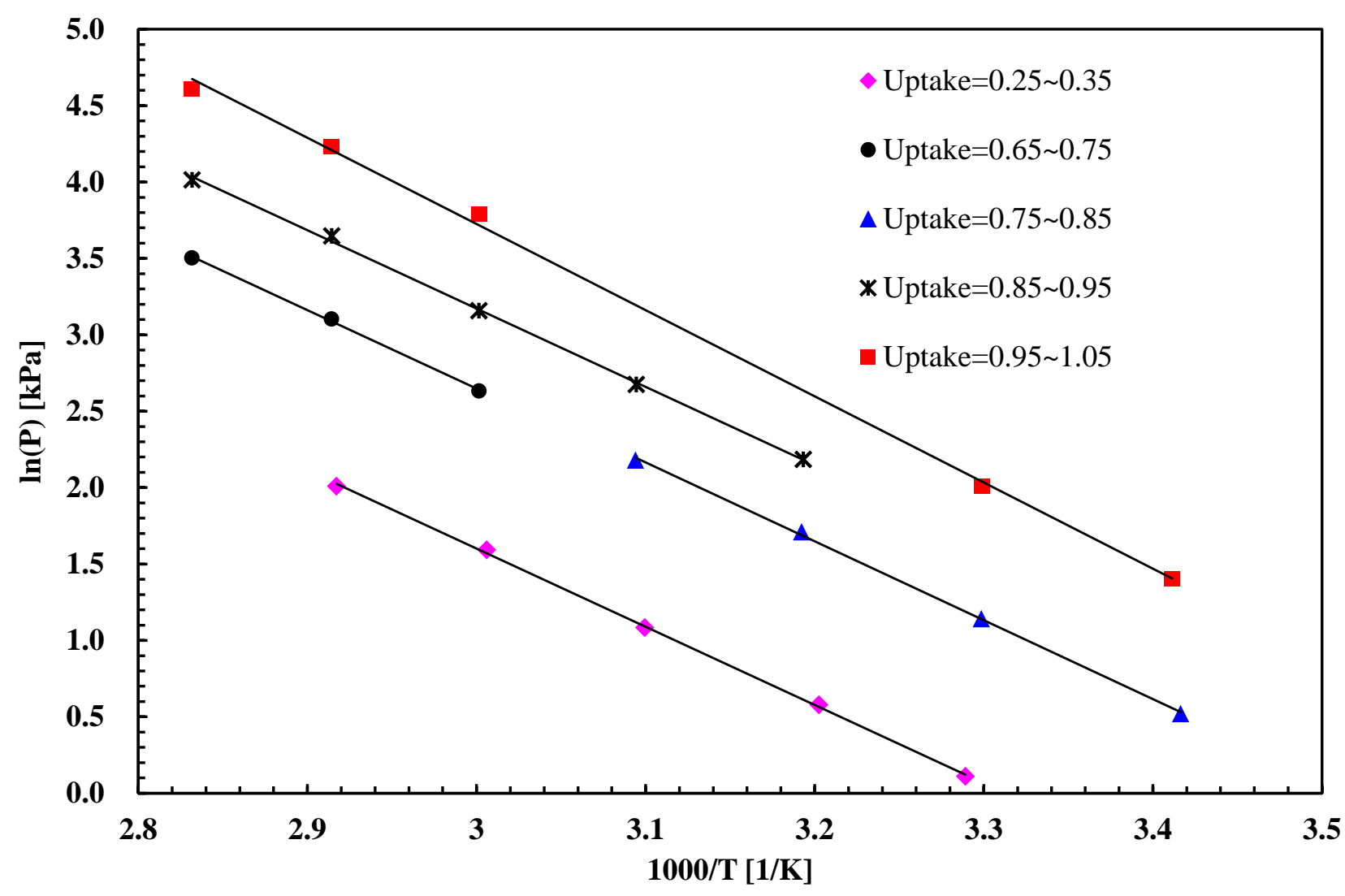

Fig. 7(b). Plot of $\ln (P)$ vs $1 / T$ at different uptake range for $\mathrm{KOH}-\mathrm{H}_{2}$ treated Maxsorb III/ethanol pair. 


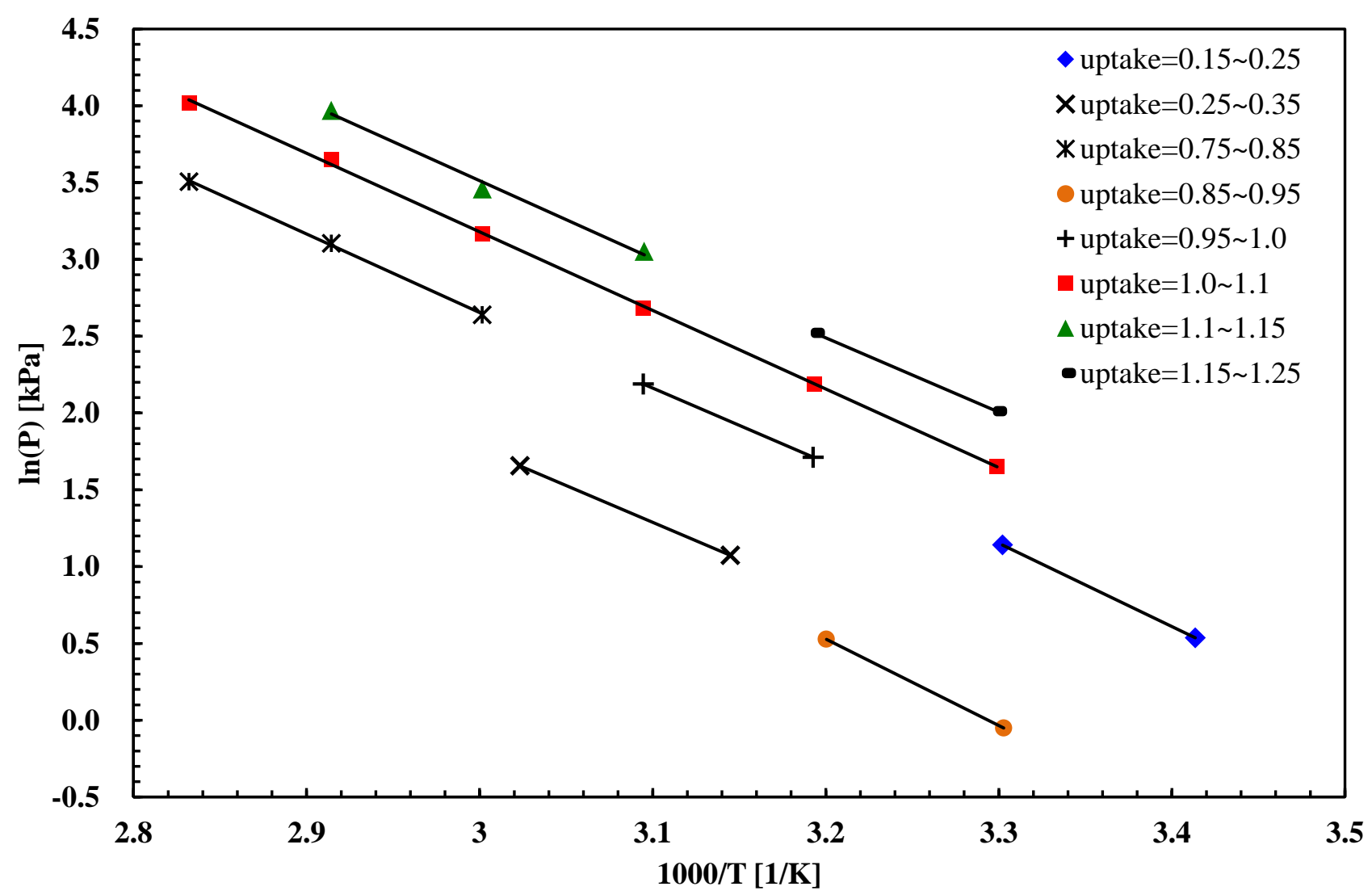

Fig. 7(c). Plot of $\ln (P)$ vs $1 / T$ at different uptake range for $\mathrm{H}_{2}$ treated Maxsorb III/ethanol pair. 


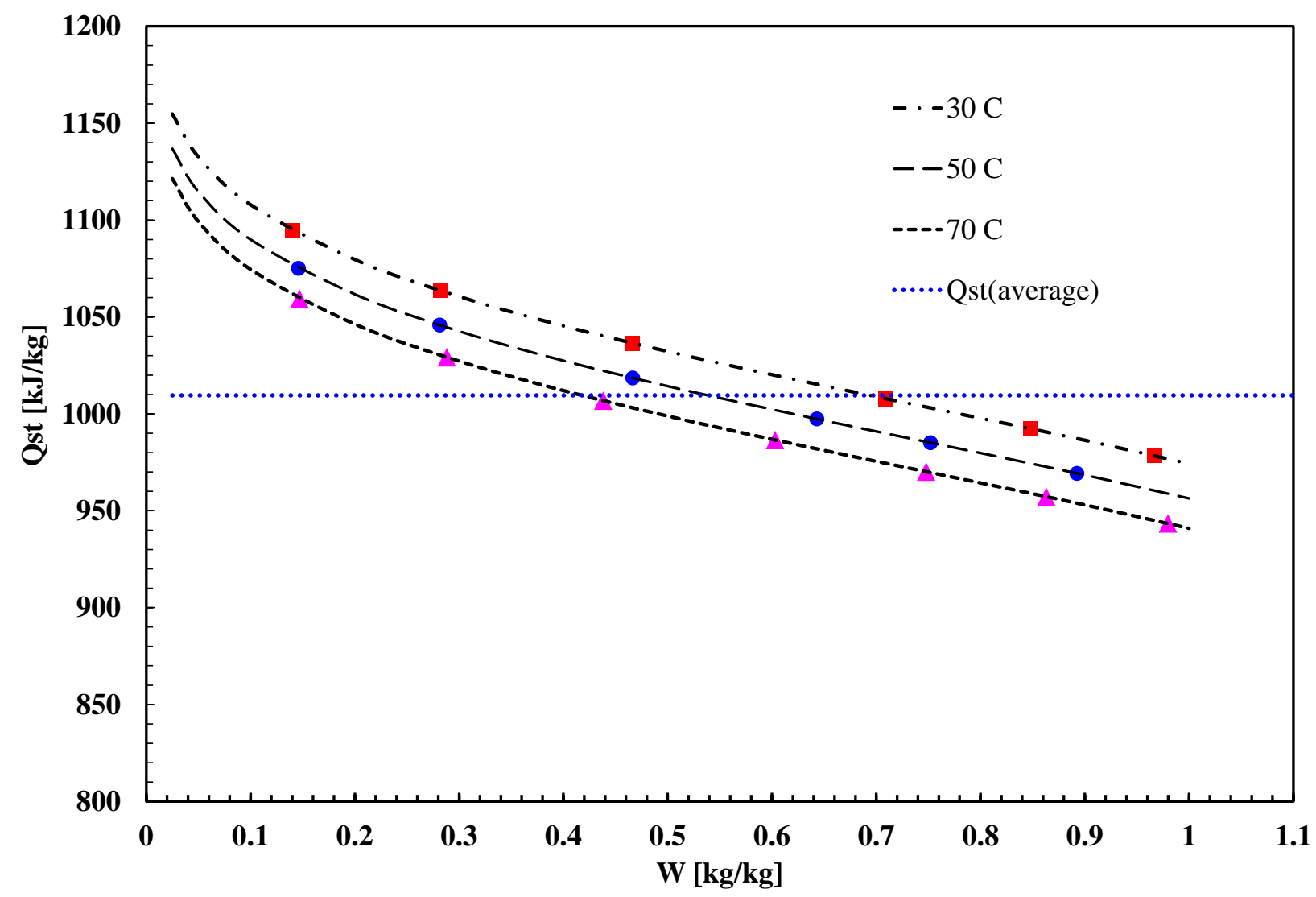

Fig. 8(a). Isosteric heat of adsorption of ethanol onto parent Maxsorb III/ethanol pair. 


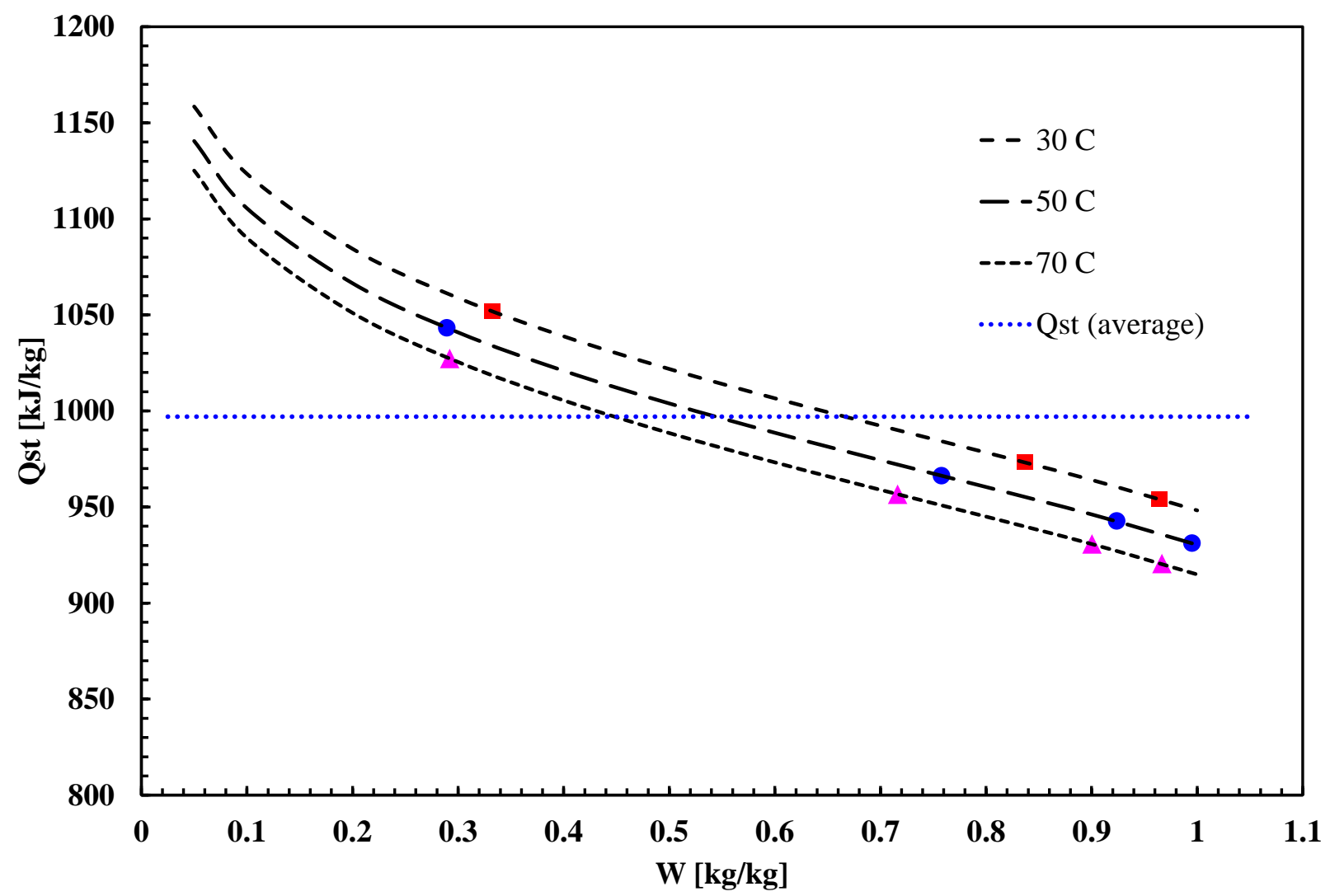

Fig. 8(b). Isosteric heat of adsorption of ethanol onto $\mathrm{KOH}-\mathrm{H}_{2}$ treated Maxsorb III/ethanol pair. 


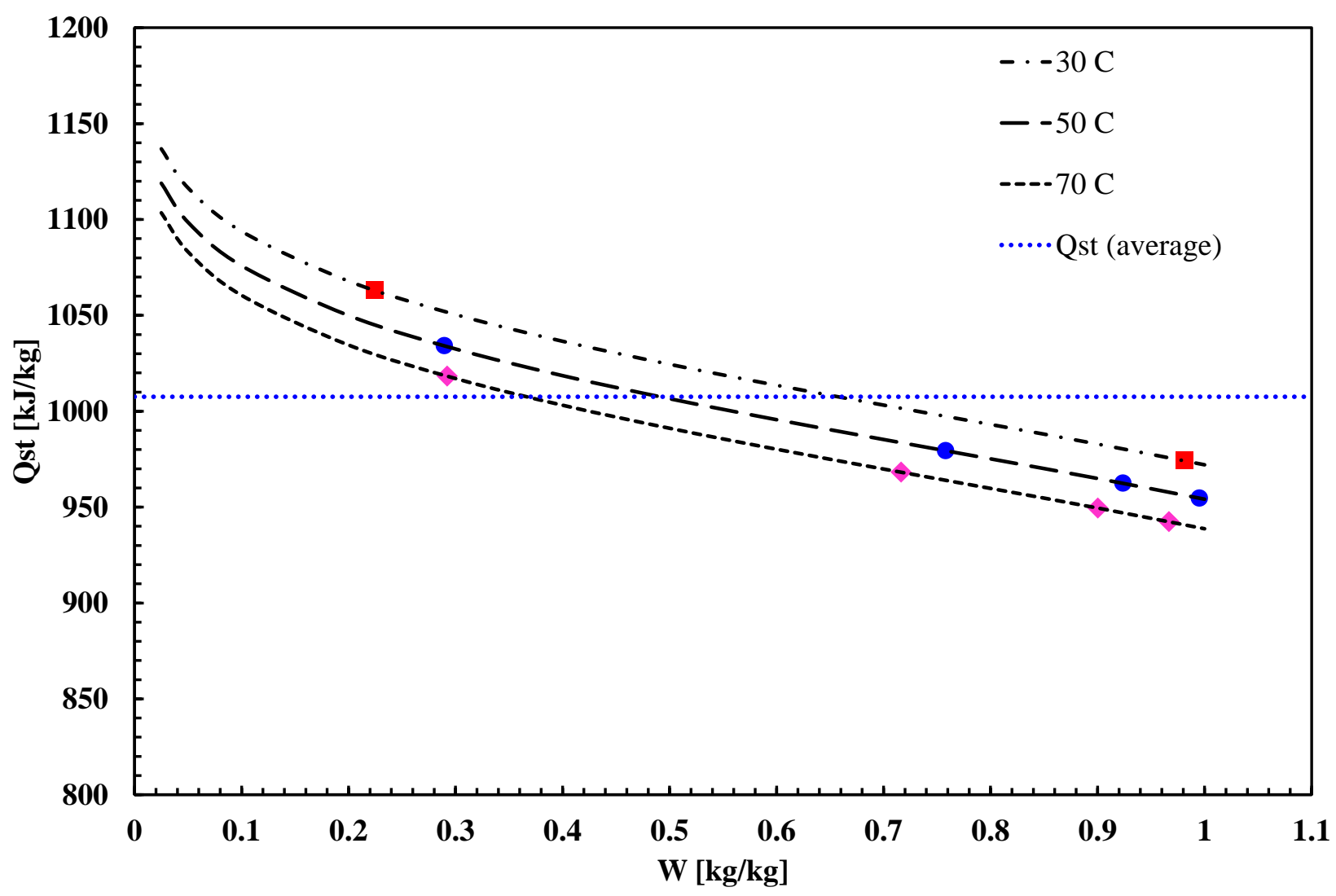

Fig. 8(c). Isosteric heat of adsorption of ethanol onto $\mathrm{H}_{2}$ treated Maxsorb III/ethanol pair. 


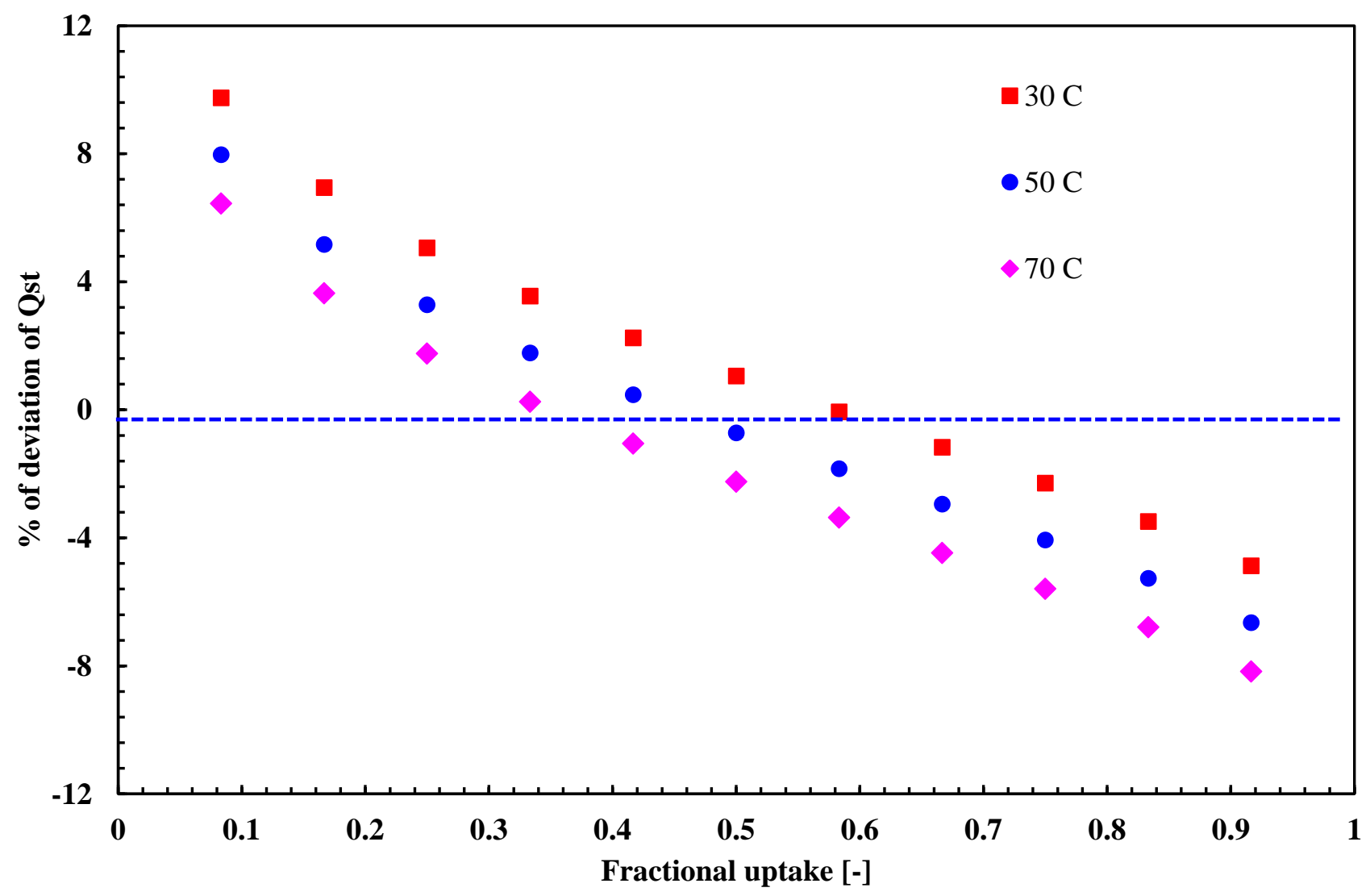

Fig. 9. Percentage of deviation of isosteric heat from its average value for parent Maxsorb III/ethanol pair. 


\section{List of Tables}

Table 1 Elemental composition of adsorbents [23].

Table 2 Composition of ethanol used in experiment.

Table 3 Adsorption parameters of assorted adsorbent/refrigerant pairs. 
Table 1

Elemental composition of adsorbents [23].

\begin{tabular}{|c|c|c|c|c|c|c|c|}
\hline \multirow{3}{*}{ Sample } & \multicolumn{5}{|c|}{ Elemental composition } & \multirow{2}{*}{$\begin{array}{c}\text { Surface } \\
\text { area }\end{array}$} & \multirow{2}{*}{$\begin{array}{c}\text { Micropore } \\
\text { volume }\end{array}$} \\
\hline & $\mathrm{C}$ & $\mathrm{H}$ & $\mathrm{N}$ & $\mathrm{O}$ & Ash & & \\
\hline & {$[\%]$} & {$[\%]$} & {$[\%]$} & {$[\%]$} & {$[\%]$} & {$\left[\mathrm{m}^{2} / \mathrm{g}\right]$} & {$\left[\mathrm{cm}^{3} / \mathrm{g}\right]$} \\
\hline Parent Maxsorb III & 95.13 & 0.14 & 0.25 & 4.35 & 0.13 & 3045 & 1.70 \\
\hline $\mathrm{KOH}-\mathrm{H}_{2}$-Maxsorb III & 89.15 & 0.27 & 0.08 & 10.46 & - & 2992 & 1.65 \\
\hline $\mathrm{H}_{2}$-Maxsorb III & 97.91 & 0.22 & 0.12 & 1.75 & - & 3029 & 1.73 \\
\hline
\end{tabular}




\section{Table 2}

Composition of ethanol used in experiment.

\begin{tabular}{|c|c|}
\hline Component & Specification \\
\hline Ethanol & $94.8-95.8$ vol. $\%$ \\
\hline Density $\left(20^{\circ} \mathrm{C}\right)$ & $0.808-0.812 \mathrm{~g} / \mathrm{ml}$ \\
\hline Residue after evaporation & Max. $0.001 \%$ (mass/mass) \\
\hline Acidity (as $\mathrm{CH}_{3} \mathrm{COOH}$ ) & Max. $0.002 \%$ (mass/mass) \\
\hline Alkalinity $\left(\right.$ as $\left.\mathrm{NH}_{3}\right)$ & Max. 1 ppm (mass/mass) \\
\hline Heavy metals (as $\mathrm{Pb}$ ) & Max. 1ppm (mass/mass) \\
\hline $\begin{array}{l}\text { Aldehydes \& ketones (as } \\
\left.\qquad \mathrm{CH}_{3} \mathrm{COCH}_{3}\right)\end{array}$ & Max. $0.001 \%$ (mass $/$ mass) \\
\hline $\begin{array}{c}\text { 1-butanol }\left[\mathrm{CH}_{3}\left(\mathrm{CH}_{2}\right)_{2} \mathrm{CH}_{2} \mathrm{OH}\right] \\
(\mathrm{GC})\end{array}$ & Mas. $0.005 \%$ (mass/mass) \\
\hline 1-propanol $\left[\mathrm{CH}_{3} \mathrm{CH}_{2} \mathrm{CH}_{2} \mathrm{OH}\right](\mathrm{GC})$ & Max. $0.005 \%$ (mass/mass) \\
\hline 2-propanol $\left[\left(\mathrm{CH}_{3}\right)_{2} \mathrm{CHOH}\right](\mathrm{GC})$ & Max. 0.01\% (mass/mass) \\
\hline Methanol $\left[\mathrm{CH}_{3} \mathrm{OH}\right](\mathrm{GC})$ & Max. $0.02 \%$ (mass/mass) \\
\hline $\begin{array}{c}\text { 3-methyl-1-butanol } \\
{\left[\left(\mathrm{CH}_{3}\right)_{2} \mathrm{CHCH}_{2} \mathrm{CH}_{2} \mathrm{OH}\right](\mathrm{GC})}\end{array}$ & Max. $0.004 \%$ (mass $/ \mathrm{mass}$ ) \\
\hline
\end{tabular}




\section{Table 3}

Adsorption parameters of assorted adsorbent/refrigerant pairs.

\begin{tabular}{cccc}
\hline Sample & $\mathrm{W}_{0}[\mathrm{~kg} / \mathrm{kg}]$ & $\mathrm{n}[-]$ & $\mathrm{E}[\mathrm{J} / \mathrm{mol}]$ \\
\hline Parent Maxsorb III & 1.24 & 1.9 & 5265 \\
\hline $\mathrm{KOH}-\mathrm{H}_{2}$ treated Maxsorb III & 1.09 & 1.6 & 5331 \\
\hline $\mathrm{H}_{2}$ treated Maxsorb III & 1.25 & 1.9 & 4780 \\
\hline
\end{tabular}

